\title{
Site M0064
}

T. Andrén, B.B. Jørgensen, C. Cotterill, S. Green, E. Andrén, J. Ash, T. Bauersachs, B. Cragg, A.-S. Fanget, A. Fehr, W. Granoszewski, J. Groeneveld, D. Hardisty, E. Herrero-Bervera,

O. Hyttinen, J.B. Jensen, S. Johnson, M. Kenzler, A. Kotilainen, U. Kotthoff, I.P.G. Marshall, E. Martin, S. Obrochta, S. Passchier, N. Quintana Krupinski, N. Riedinger, C. Slomp, I. Snowball, A. Stepanova, S. Strano, A. Torti, J. Warnock, N. Xiao, and R. Zhang ${ }^{2}$

\section{Chapter contents}

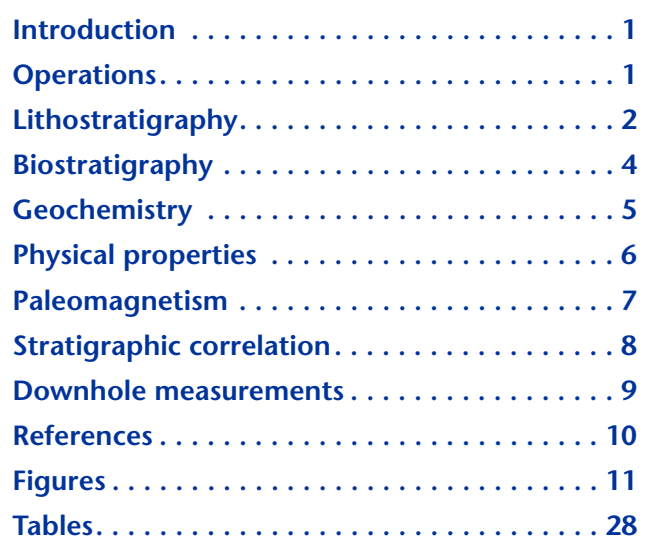

${ }^{1}$ Andrén, T., Jørgensen, B.B., Cotterill, C., Green, S., Andrén, E., Ash, J., Bauersachs, T., Cragg, B., Fanget, A.-S., Fehr, A., Granoszewski, W., Groeneveld, J., Hardisty, D., Herrero-Bervera, E., Hyttinen, O., Jensen, J.B., Johnson, S., Kenzler, M. Kotilainen, A., Kotthoff, U., Marshall, I.P.G., Martin, E., Obrochta, S., Passchier, S., Quintana Krupinski, N., Riedinger, N., Slomp, C., Snowball, I., Stepanova, A., Strano, S., Torti, A., Warnock, J., Xiao, N., and Zhang, R., 2015. Site M0064. In Andrén, T., Jørgensen, B.B., Cotterill, C., Green, S., and the Expedition 347 Scientists, Proc. IODP, 347: College Station, TX (Integrated Ocean Drilling Program)

doi:10.2204/iodp.proc.347.108.2015

'Expedition 347 Scientists' addresses.

\section{Introduction}

During Integrated Ocean Drilling Program (IODP) Expedition 347, cores were recovered from four holes at Site M0064 (Hanö Bay), with an average site recovery of $79 \%$. The water depth was $60.5 \mathrm{~m}$ in Hole M0064A and $59.8 \mathrm{~m}$ in the other three holes, with a tidal range of $<10 \mathrm{~cm}$. Existing data sets, including seismic reflection profiles, were evaluated prior to each site to attempt to guide the initial drilling with an anticipated lithologic breakdown. The total time spent on station was 2.89 days.

\section{Operations}

\section{Transit to Hole M0064A}

The Greatship Manisha commenced transit to Site M0064 (proposed Site BSB-5) in Hanö Bay at 1215 h on 19 October 2013 and arrived on station by $1200 \mathrm{~h}$ on 20 October.

\section{Hole M0064A}

Operations in Hole M0064A commenced at $1200 \mathrm{~h}$ on 20 October 2013 with a remotely operated vehicle survey conducted to assess the seabed for the presence of WWII munitions. The survey covered Holes M0064A, M0064B, and M0064C. No evidence of any dangerous materials on the seabed was identified.

Following the survey, the vessel moved back to Hole M0064A and coring operations commenced (Table T1). The first four runs used the piston corer system (PCS) to recover clay. For Run 5, the nonrotating core barrel (NRCB) was used because of the presence of stiffer material indicative of the top of the diamicton unit. Run 6 used the push coring assembly (PCA) in an attempt to improve recovery. Following this, Runs 7-24 (16.05-34.5 meters below seafloor [mbsf]) used the NRCB, and Guar replaced seawater for pumping because of the increased sand content of the sediments. Run 25 was a PCA core, after a perceived failure to latch with the NRCB (no core recovered). Following the PCA, the string was flushed. The NRCB was lowered on the overshot, and latching was achieved. Coring with the NRCB continued for Runs 26-30. Runs 29 and 30 had no recovery, so a hammer sample (Run 31) was taken to prove the ground. The hammer sample recovered $0.08 \mathrm{~m}$ of gravel. The final NRCB (Run 32) core recovered $0.15 \mathrm{~m}$ of gravel with chalk beneath. 
A total of 32 cores were recovered from Hole M0064A to 41.5 mbsf. Recovery for the hole was $66.82 \%$.

Downhole logging operations started on 21 October at 1300 with drill pipe tripped to $1.5 \mathrm{~m}$. The first tool string with the total gamma ray and induction tools reached only 5 mbsf. At $1515 \mathrm{~h}$, the option of reaming the pipe to total depth, doing a wiper trip, and setting the pipe to $10.5 \mathrm{~m}$ was discussed, but as the ship required a heading change, the decision was made to abandon the downhole logging attempt at this hole. Logging operations were completed at $1520 \mathrm{~h}$.

\section{Hole M0064B}

Following completion of operations in Hole M0064A, the vessel moved to Hole M0064B under dynamic positioning, and operations commenced at $1605 \mathrm{~h}$ on 21 October 2013. The second PCS run (3.3-6.6 mbsf) unexpectedly recovered coarsegrained sand. A third PCS run was attempted, with poor recovery. It was therefore decided to open hole in order to try and penetrate the sand feature. A final hammer sample taken at $10.1 \mathrm{mbsf}$ confirmed that sand was still present at this depth, and because of potential damage to drilling equipment and the unanticipated lithology, the hole was terminated here.

A total of four cores were recovered from Hole M0064B to a maximum depth of 10.20 mbsf, with one open-hole section. Recovery for the hole was $96.94 \%$ when the open-hole section was discounted.

\section{Hole M0064C}

The vessel arrived over Hole M0064C at $1915 \mathrm{~h}$ on 21 October 2013, and drilling operations commenced. The first PCS core was recovered to deck at $1925 \mathrm{~h}$. Three more PCS cores were recovered to deck before the top of the diamicton unit necessitated use of the NRCB.

Coring in Hole M0064C continued on 22 October, with 21 cores recovered by midday. This included one small interval of open holing to clean the hole and penetrate a possible obstruction that had resulted in zero recovery from the previous core run. Following a significant drop in recovery rates at 38.2 mbsf, a hammer sample was conducted to ascertain the exact lithology. Following this, five more NRCB cores were taken, with very limited recovery of rounded pebbles and gravel. A final hammer sample returned granite and chalk basement. The hole was terminated at target depth. Preparations were made for downhole logging. However, despite the hole being flushed and wiper trips being carried out to condition the hole, the hole collapsed from 9 mbsf. It was therefore not possible to conduct any logging operations.

A total of 35 core attempts were made in Hole M0064C, with one open-hole section of $2 \mathrm{~m}$. The hole reached $45.10 \mathrm{mbsf}$, and hole recovery was $74.98 \%$ when the open-hole section was discounted.

\section{Hole M0064D}

Operations in Hole M0064D began at 1555 h on 22 October 2013. Based on the lithologies observed in the other holes at this site, it was decided that this hole should be cored at a new location, midway between Holes M0064A and M0064C, in an attempt to avoid the sand unit encountered in Hole M0064B and prevent the need for a second camera survey (as this hole lay on the A-C transect surveyed initially).

Operations began successfully in Hole M0064D with five piston cores being recovered. During recovery of the fifth core, a spline came off the overshot, but this was successfully retrieved using a magnet. As a soft diamicton was recovered in this run, the decision was made to change to the NRCB and continue operations.

NRCB Runs 6-13 recovered material from the diamicton layer to 23.4 mbsf. Run 14 was an open-hole run, using the insert bit to clear a blockage. Following this run, NRCB coring resumed to 33.90 mbsf. At this point, it was no longer possible to core, so an open-hole section was drilled, ending at $41.0 \mathrm{mbsf}$ where a hammer sample was taken to prove the ground. The hammer sample recovered $0.2 \mathrm{~m}$ of gravel.

This marked the end of the hole (at $0755 \mathrm{~h}$ on 23 October), and the drill floor was prepared for downhole logging operations.

Downhole logging operations started in Hole M0064D on 23 October at $0715 \mathrm{~h}$ with rigging up the Weatherford logging setup while the drill pipe was tripped to 9 mbsf. The first tool string comprising the total gamma ray and induction tools reached $31 \mathrm{mbsf}$, and the second tool string comprising total gamma and spectral gamma ray tools reached 26 mbsf from where an uplog was started. Logging operations were finished at $1035 \mathrm{~h}$.

A total of 21 cores were recovered from Hole M0064D. A further four recorded runs were openhole sections with no recovery attempted. Hole recovery was $77.94 \%$ when open-hole sections were discounted.

\section{Lithostratigraphy}

At Site M0064, four holes were drilled: Hole M0064A to a total depth of 41.5 mbsf, Hole M0064B to 10.2 
mbsf, Hole M0064C to 45.10 mbsf, and Hole M0064D to 41.2 mbsf. The top $\sim 12$ to $\sim 15 \mathrm{~m}$ in each hole was retrieved by piston coring with nearly $100 \%$ recovery in Holes M0064A, M0064C, and M0064D. Hole M0062B terminated in a sand and gravel deposit (Fig. F1). Deeper than $\sim 15 \mathrm{mbsf}$, the nonrotating core barrel was used to $\sim 35 \mathrm{mbsf}$, with $\sim 50 \%$ recovery in each hole, encountering different formation depths within each hole. A combination of nonrotating core barrel, push coring, open holing, and hammer sampling achieved advancement of the drill bit with nearly $100 \%$ recovery between $\sim 35$ and 38 mbsf in Holes M0064A and M0064C but with limited recovery deeper than this depth (see "Operations").

Lithostratigraphic divisions (Units I-IV; Fig. F2) are based on descriptions on the cut face of the split core and observations from smear slides (see "Core descriptions"). Units I and II are absent in Holes M0064B and M0064C.

\section{Unit I}

Intervals: $347-\mathrm{M} 0064 \mathrm{~A}-1 \mathrm{H}-1,0 \mathrm{~cm}$, to $1 \mathrm{H}-1,33$ $\mathrm{cm}$; 347-M0064D-1H-1, $0 \mathrm{~cm}$, to $1 \mathrm{H}-1,134 \mathrm{~cm}$

Depths: Hole M0064A $=0-0.33$ mbsf; Hole M0064D = 0-1.34 mbsf

Unit I is very dark greenish gray diatom-bearing clay, 0.33 to $1.34 \mathrm{~m}$ thick, largely homogeneous, but with weak parallel planar laminations at the base of the unit (Fig. F3). Laminae are black in color, and a smear slide from the base of the unit reveals a relatively large amount of opaque, possibly iron sulfide, minerals.

This unit was likely deposited in a brackish marine or lake environment with low terrigenous sediment input. For the base of the unit, a stratified water column, low oxygen, and a lack of benthic life may have allowed for preservation of lamination. Accumulation of organic matter may have formed the precursor to the iron sulfide minerals.

\section{Unit II}

Intervals: $347-\mathrm{M} 0064 \mathrm{~A}-1 \mathrm{H}-1,33 \mathrm{~cm}$, to $1 \mathrm{H}-1,60$ $\mathrm{cm}$; 347-M0064D-1H-1, $134 \mathrm{~cm}$, to $1 \mathrm{H}-2,25 \mathrm{~cm}$

Depths: Hole M0064A $=0.33-0.6$ mbsf; Hole $\mathrm{M} 0064 \mathrm{D}=1.34-1.75 \mathrm{mbsf}$

Unit II is greenish gray to very dark greenish gray sandy silt, 0.27 to $0.41 \mathrm{~m}$ thick. The silt is stratified with a coarser, more sand-rich upper part (Fig. F3). No fossils were found in the unit.

The sediment probably represents deposition in a shallow, oxidized, proglacial lake environment with relatively high terrigenous sedimentation rates.

\section{Unit III}

\section{Subunit IIIa}

Intervals: $347-\mathrm{M} 0064 \mathrm{~A}-1 \mathrm{H}-1,60 \mathrm{~cm}$, to $3 \mathrm{H}-1,85$ $\mathrm{cm}$; 347-M0064B-1H-1, $0 \mathrm{~cm}$, to $1 \mathrm{H}-3,24 \mathrm{~cm}$; $347-\mathrm{M} 0064 \mathrm{C}-1 \mathrm{H}-1,0 \mathrm{~cm}$, to $2 \mathrm{H}-2,116 \mathrm{~cm} ; 347-$ M0064D-1H-2, $25 \mathrm{~cm}$, to $3 \mathrm{H}-2,87 \mathrm{~cm}$

Depths: Hole M0064A $=0.6-7.15 \mathrm{mbsf}$; Hole M0064B = 0-2.94 mbsf; Hole M0064C $=0-5.96$ mbsf; Hole M0064D = 1.75-7.87 mbsf

\section{Subunit IIIb}

Intervals: $347-\mathrm{M} 0064 \mathrm{~A}-3 \mathrm{H}-1,85 \mathrm{~cm}$, to $3 \mathrm{H}-2,73$ $\mathrm{cm}$; 347-M0064B-1H-3, $24 \mathrm{~cm}$, to $2 \mathrm{H}-1,130 \mathrm{~cm}$; $347-\mathrm{M} 0064 \mathrm{C}-2 \mathrm{H}-2,116 \mathrm{~cm}$, to $3 \mathrm{H}-1,69 \mathrm{~cm}$; 347-M0064D-3H-2, $87 \mathrm{~cm}$, to $4 \mathrm{H}-1,50 \mathrm{~cm}$

Depths: Hole M0064A = 7.15-8.53 mbsf; Hole M0064B = 2.94-4.6 mbsf; Hole M0064C = 5.967.29 mbsf; Hole M0064D = 7.87-9.3 mbsf

Unit III is dark grayish brown laminated clay and silty clay with dispersed clasts. The clay is rhythmically laminated by color on a centimeter scale and locally contains dispersed gravel clasts, sand, and sedimentary intraclasts. Inclined laminae and synsedimentary microfaults are also observed. Lamination is planar, parallel, and inclined, and in Subunit IIIb, it comprises distinct varve-like fining-upward silty clay to clay couplets. Subunit IIIa is more brown in color, whereas Subunit IIIb is more gray with an increase in silt toward the bottom of the unit. The bottom $3 \mathrm{~cm}$ of Subunit IIIa is dark brown and forms the boundary between Subunits IIIa and IIIb (Fig. F3). The contact between Subunits IIIa and IIIb is distinct in color, but there is no change in sediment texture and the lamination has a consistent orientation across the subunit boundary.

Deposition in a glacial lake is inferred for this unit. The inclined laminae, synsedimentary microfaults, and sedimentary intraclasts may indicate minor slumping due to an unstable sloping environment or high sedimentation rates. Outsized gravel clasts probably represent ice rafting.

\section{Unit IV}

\section{Subunit IVa}

Intervals: $347-\mathrm{M} 0064 \mathrm{~A}-3 \mathrm{H}-2,73 \mathrm{~cm}$, to $18 \mathrm{~N}-1,0$ $\mathrm{cm}$; 347-M0064B-2H-1, $130 \mathrm{~cm}$, to $5 \mathrm{~S}-1,10 \mathrm{~cm}$; $347-\mathrm{M} 0064 \mathrm{C}-3 \mathrm{H}-1,69 \mathrm{~cm}$, to $17 \mathrm{~N}-1,0 \mathrm{~cm} ; 347-$ M0064D-4H-1, $50 \mathrm{~cm}$, to $15 \mathrm{~N}-1,0 \mathrm{~cm}$

Depths: Hole M0064A $=8.53-26.5$ mbsf; Hole $\mathrm{M} 0064 \mathrm{~B}=4.6-10.2$ mbsf; Hole M0064C = 7.29_ 25.7 mbsf; Hole M0064D = 9.3-25.4 mbsf 


\section{Subunit IVb}

Intervals: $347-\mathrm{M} 0064 \mathrm{~A}-18 \mathrm{~N}-1,0 \mathrm{~cm}$, to $26 \mathrm{~N}-1,85$ $\mathrm{cm}$; $347-\mathrm{M} 0064 \mathrm{C}-17 \mathrm{~N}-1,0 \mathrm{~cm}$, to $28 \mathrm{~N}-1,0 \mathrm{~cm}$; 347-M0064D-15N-1, $0 \mathrm{~cm}$, to end of hole

Depths: Hole M0064A = 26.5-36.35 mbsf; Hole M0064C $=25.7-36.7$ mbsf; Hole M0064D = 25.4-41.20 mbsf

\section{Subunit IVc}

Intervals: $347-\mathrm{M} 0064 \mathrm{~A}-26 \mathrm{~N}-1,85 \mathrm{~cm}$, to end of hole; $347-\mathrm{M} 0064 \mathrm{C}-28 \mathrm{~N}-1,0 \mathrm{~cm}$, to end of hole

Depths: Hole M0064A = 36.35-41.5 mbsf; Hole $\mathrm{M0064C}=36.7-45.0 \mathrm{mbsf}$

Unit IV is composed of moderately to poorly sorted coarse-grained sediments with variable gravel abundances and sand content in the matrix. Subunit IVa consists primarily of clast-rich stratified muddy diamicton and sandy gravel. Within the diamicton, contorted mud stringers and laminae, as well dark color banding, are observed (Fig. F3). Subunit IVb is dominated by massive, clast-poor, sandy diamicton (Fig. F3). Occasional potential clast alignment fabrics were observed in this facies. Subunit IVc consists of stratified sandy clayey silt with dispersed clasts and thin intervals of diamicton. In this latter subunit, a large variation in clast abundances is observed over relatively short depth intervals.

Unit IV was deposited in an ice-influenced depositional environment. Subunit IVa shows evidence of meltwater flow and minor gravity flow, as well as features of an ice-contact outwash plain. Subunit IVb probably represents an ice-proximal deposit with massive diamicton originating from either subglacial processes, glacigenic debris flow, or glaciomarine/ glaciolacustrine deposition. Subunit IVc likely originated in an ice-influenced aquatic depositional environment, with variations in clast abundances due to changes in glaciomarine or glaciolacustrine deposition.

\section{Biostratigraphy}

\section{Diatoms}

Qualitative analysis of diatom community composition was carried out on one sample from Site M0064 (Table T2). Sample 347-M0064A-1H-1, 0 cm, contains a typical Baltic Sea assemblage (Andrén et al., 2000; Snoeijs et al., 1993-1998). This assemblage contains both diatoms and chrysophycean cysts. All other samples from Hole M0064A and all samples from Holes M0064B and M0064C, including core tops, were barren of siliceous microfossils. Reworked Cretaceous foraminifers and coccolithophorids were found in Section 347-M0064C-3H-2, $0 \mathrm{~cm}$.

\section{Foraminifers and ostracods}

A total of 29 samples (21 taken offshore from core catchers and 8 from regular sections during the Onshore Science party [OSP]) from Site M0064 were prepared for foraminiferal and ostracod analysis. Foraminifers do not occur in the sediments sampled at this site. The lack of foraminifers suggests that low oxygen and/or salinity may have prevented the occurrence of foraminifers in the basin. Almost no microfossils $>63 \mu \mathrm{m}$ were present, even in the upper dark brown sediment (Unit I, Core 1, Section 1 in each hole), potentially suggesting low-oxygen conditions, a theory supported by the laminated nature of sediments in this interval (see "Lithostratigraphy"). However, a few testate amoebae occurred in Sample 347-M0064D-1H-1, 15-17 cm.

Only one juvenile ostracod valve of Paracyprideis sp. was found at this site at 0.16 mbsf in Hole M0064D; the sediments were otherwise barren with respect to ostracods.

\section{Palynological results}

Site M0064 is situated in the central part of the southern Baltic Sea. The vegetation of the borderlands in that region belongs to the cool temperate forest zone with mixed coniferous and deciduous trees. However, the boreal-forest vegetation zone is very close to the site. The palynological analyses for this site were carried out on Hole M0064A.

A total of 12 samples from Hole M0064A were analyzed (see PalyM0064.xls in PALYNOLOGY in "Supplementary material"). However, the palynomorphs in all samples appeared to have been degraded/oxygenated to a high degree, and no sample contained enough palynomorphs in situ to yield statistically relevant data. Only five samples contained in situ pollen preserved well enough to identify nonsaccate pollen. The pollen concentration per cubic centimeter varied from 0 to 1000 grains, which is a factor 500 to 1000 lower than the concentration encountered in samples with good preservation at other sites.

Two samples from the depth interval of $\sim 6.5-8.5$ mbsf contain a few Pinus (pine), Picea (spruce), Betula (birch), Juniperus (juniper), and Quercus (oak) pollen grains. The sample at $\sim 6.5$ mbsf furthermore contains several steppe element pollen grains (Artemisial Chenopodiacea). This assemblage may imply a late glacial/early Holocene age, but as stated above, the statistical relevance of the data is too low for a reliable age estimate.

Samples deeper than $\sim 15$ mbsf contain high amounts of degraded material, and there were often more reworked than in situ pollen. In Sample 347- 
M0064A-12H-CC, the number of reworked dinoflagellate cysts surpassed that of reworked pollen grains. Some of these cysts could be identified to the genus level and thus allowed age estimation for the reworked material. The genera comprise Apectodinium, Wetzeliella, and Charlesdowniea (Fig. F4). The reworked material thus is of Paleogene origin (Powell, 1992; K. Dybkjær, pers. comm., 2014). Reworked pollen includes Picea and Pinus as well as Carya pollen grains.

\section{Geochemistry}

\section{Interstitial water}

Pore water samples from Site M0064 were recovered from the upper $16 \mathrm{~m}$ of the cored interval. For Holes M0064A, M0064C, and M0064D, this interval is composed of diamicton overlain by 7-9 $\mathrm{m}$ of glacial lake clays (see "Lithostratigraphy" and "Biostratigraphy"). For Hole M0063B, the lake clays transition into a sand layer at 4.6 mbsf. Low organic matter concentrations in these sediments and the presentday brackish conditions at the site govern the pore water profiles.

\section{Salinity variations: chloride, salinity, and alkalinity}

Pore water chloride $\left(\mathrm{Cl}^{-}\right)$and salinity profiles (Fig. F5A-F5B; Tables T3, T4) illustrate good agreement between holes and between salinity measurements made shipboard with a refractometer and derived from $\mathrm{Cl}^{-}\left(\mathrm{Cl}^{-}\right.$based salinity; Fig. F5C). Salinity is 1314 in the shallowest sample at $1.35 \mathrm{mbsf}$, increases to $\sim 15$ at $6-8 \mathrm{mbsf}$, and then drops again to 11-12 toward the bottom of the holes. Alkalinity values are very low at Site M0064 (2-5 meq/L), with minor differences between holes; in Holes M0064A and M0064D, alkalinity decreases from $\sim 6 \mathrm{meq} / \mathrm{L}$ at the surface to $3 \mathrm{meq} / \mathrm{L}$ at depth, whereas in Holes M0064B and M0064C alkalinity is relatively constant between 3 and 4 meq/L (Fig. F5D).

\section{Organic matter degradation: sulfate, ammonium, phosphate, iron, manganese, $\mathrm{pH}$, bromide, and boron}

No methane or hydrogen sulfide measurements were conducted at this site. Pore waters record evidence of only minor organic matter degradation likely due to the overall low concentrations of organic matter in the sediments (see below). Sulfate $\left(\mathrm{SO}_{4}{ }^{2-}\right)$ decreases from $10 \mathrm{mM}$ in the shallowest samples to $5 \mathrm{mM}$ at depth (Fig. F6A). A plot of $\mathrm{SO}_{4} / \mathrm{Cl}$ (Fig. F6B) suggests that the $\mathrm{SO}_{4}{ }^{2-}$ depletion represents sulfate reduction rather than dilution by low-salinity pore waters.

Pore water ammonium $\left(\mathrm{NH}_{4}{ }^{+}\right.$; Fig. F6C) indicates minor release from organic matter degradation, with values of $0.1-0.3 \mathrm{mM}$ in the shallowest samples increasing to $0.4 \mathrm{mM}$ at depth (Table T3). Pore water phosphate $\left(\mathrm{PO}_{4}{ }^{3-}\right)$ concentrations are low $(\sim 0.01$ $\mathrm{mM}$ ) throughout most of the sampled interval, with a peak of $0.05 \mathrm{mM}$ in the uppermost $3 \mathrm{mbsf}$ (Fig. F6D). Both dissolved iron $\left(\mathrm{Fe}^{2+}\right)$ and manganese $\left(\mathrm{Mn}^{2+}\right)$ concentrations are scattered with broad peaks at 5-10 mbsf (Fig. F6E-F6F). Dissolved $\mathrm{Fe}^{2+}$ concentrations peak at $\sim 200 \mu \mathrm{M}$, whereas in Hole M0064D the deepest sample returns to a higher value of 230 $\mu \mathrm{M}$. Dissolved $\mathrm{Mn}^{2+}$ concentrations peak at $60-70$ $\mu \mathrm{M}$, with values of $20-30 \mu \mathrm{M}$ in the shallowest samples and 10-25 $\mu \mathrm{M}$ in the deepest samples. $\mathrm{pH}$ has a slight and broad minimum of $\sim 7.5$ at 5-10 mbsf, with values of $\sim 7.7$ at the top and bottom of the sampled interval (Fig. F6G).

Pore water bromide $\left(\mathrm{Br}^{-}\right)$concentrations (Fig. F7A) vary over a narrow range of $0.27-0.35 \mathrm{mM}$ and follow the pattern observed for salinity and $\mathrm{Cl}^{-}$such that the $\mathrm{Br} / \mathrm{Cl}$ ratio is almost constant with depth (Fig. F7B), reflecting the seawater ratio. All holes have a similar pattern for boron (B), with surface concentrations of $150-190 \mu \mathrm{M}$ that decrease to $\sim 60$ $\mu \mathrm{M}$ by 6 mbsf and maintain similar concentrations deeper than that depth (Fig. F7C). The shallowest B/ $\mathrm{Cl}$ ratios are similar to the seawater ratio (Fig. F7D), but underlying ratios indicate uptake of $\mathrm{B}$, possibly by weathering reactions or ion exchange.

\section{Mineral reactions}

\section{Sodium, potassium, magnesium, and calcium}

Concentrations of $\mathrm{Na}^{+}$are relatively constant with depth and between holes, with a range of 130-240 $\mathrm{mM}$ (Fig. F8A; Table T3). Unlike other sites, $\mathrm{K}^{+}$profiles at Site M0064 do not follow the same pattern as $\mathrm{Na}^{+}$. Instead, the $\mathrm{K}^{+}$profile is similar to boron, with the highest concentrations of $\sim 4 \mathrm{mM}$ in the shallowest sample and values that decrease to $1.5-2 \mathrm{mM}$ before leveling off deeper than $\sim 6$ mbsf (Fig. F8B). Pore water $\mathrm{Mg}^{2+}$ profiles are similar to $\mathrm{Na}^{+}$, with a narrow range of concentrations spanning 16-23 mM with depth (Fig. F8C). Pore water $\mathrm{Ca}^{2+}$ concentrations increase gradually from $\sim 10 \mathrm{mM}$ in the shallowest samples to a broad peak of $\sim 25 \mathrm{mM}$ between 6 and 10 mbsf, depending on the hole (Fig. F8D). Element to $\mathrm{Cl}^{-}$ratios for the major cation concentrations highlight differences from seawater ratios (Fig. F8E-F8H). Both $\mathrm{Na} / \mathrm{Cl}$ and $\mathrm{Mg} / \mathrm{Cl}$ exhibit little variation from 
seawater values. Like $\mathrm{B} / \mathrm{Cl}$, the $\mathrm{K} / \mathrm{Cl}$ ratios decrease to values below the seawater ratio, again suggesting weathering reactions or ion exchange as a sink. All $\mathrm{Ca} / \mathrm{Cl}$ ratios plot well above the seawater values, indicating a solid phase source of $\mathrm{Ca}^{2+}$ at depth.

\section{Strontium, barium, lithium, and silica}

Strontium $\left(\mathrm{Sr}^{2+}\right)$ concentrations are similar to $\mathrm{Ca}^{2+}$ profiles, with a gradual increase from 40 to $55 \mu \mathrm{M}$ in the shallowest samples and a broad peak of $\sim 125 \mu \mathrm{M}$ at 8-10 mbsf (Fig. F9A). Concentration profiles of lithium $\left(\mathrm{Li}^{+}\right)$are similar to both $\mathrm{Ca}^{2+}$ and $\mathrm{Sr}^{2+}$. Li concentrations increase gradually from $\sim 10 \mu \mathrm{M}$ in the uppermost sample to a broad peak of $\sim 15 \mu \mathrm{M}$ at $8-10$ mbsf (Fig. F9B). Dissolved silica $\left(\mathrm{H}_{4} \mathrm{SiO}_{4}\right)$ concentrations increase subtly from $\sim 200 \mu \mathrm{M}$ in the shallowest sample to $\sim 325 \mu \mathrm{M}$ at $10 \mathrm{mbsf}$ (Fig. F9C). Pore water barium $\left(\mathrm{Ba}^{2+}\right)$ concentrations are very low at Site M0064, with values of $0.1-0.3 \mu \mathrm{M}$ (Fig. F9D).

\section{Sediment}

\section{Carbon content}

The total carbon (TC) content at Site M0064 varies from 0.3 to $3.5 \mathrm{wt} \%$ across holes (Table T5; Fig. F10A). The highest total organic carbon (TOC) values $(\sim 2.3 \mathrm{wt} \%)$ occur in the uppermost $\sim 0.70 \mathrm{~m}$ of the investigated profile, suggesting higher organic matter input during the more recent deposition of brackish-marine sediments, whereas the underlying freshwater and glaciolacustrine deposits are characterized by low TOC values of $<0.4 \mathrm{wt} \%$ (Table T5; Fig. F10B).

The total inorganic carbon (TIC) content at Site M0064 increases with depth in the upper $\sim 12$ mbsf, reaching values of $\sim 3.2$ wt\% (Table T5; Fig. F10C). The TIC content stays slightly elevated in the diamicton (lithostratigraphic Subunit IVa) and drops to an average value of $1.8 \mathrm{wt} \%$ deeper than $\sim 20 \mathrm{mbsf}$.

\section{Sulfur content}

The total sulfur (TS) content is generally $<0.5 \mathrm{wt} \%$ in sediments from the Hanö Bay (Table T5; Fig. F10D), with high values of $0.8-1.5 \mathrm{wt} \%$ being present only in the uppermost sediments ( $<1 \mathrm{mbsf})$. It is interesting to note that the lowest values of TS occur in the upper 1-7 mbsf (lithostratigraphic Subunit IIIa), where TOC values are slightly higher compared to the deeper sediment intervals.

\section{Physical properties}

This section summarizes the preliminary physical results from Site M0064. Four holes were drilled at this site. Hole M0064A was drilled to 41.5 mbsf, Hole
M0064B was drilled to 10.2 mbsf, Hole M0064C was drilled to $45.10 \mathrm{mbsf}$, and Hole M0064D was drilled to 41.2 mbsf. We focus on Hole M0064A because it is the only hole in which all of the lithostratigraphic units described at Site M0064 were recovered (see "Lithostratigraphy"). Although all physical property measurements described in "Physical properties" in the Methods chapter (Andrén et al., 2015) were conducted at Site M0064, discrete thermal conductivity data are too sparsely distributed to exhibit any discernable downcore trend and noncontact electrical resistivity data show little variability.

\section{Natural gamma radiation}

High-resolution natural gamma ray (NGR) exhibits relatively little variability in Hole M0064A (Fig. F11). NGR values are low within lithostratigraphic Unit I ( $\sim 7$ cps) and increase rapidly toward the base of lithostratigraphic Unit II, which could reflect lower water content in this unit (see "Lithostratigraphy"). NGR values decrease at the lithostratigraphic Unit II/ Subunit IIIa boundary and are relatively constant ( 11 cps) in lithostratigraphic Subunit IIIa. NGR exhibits an increasing trend within lithostratigraphic Subunit IIIb. The negative excursions that occur throughout lithostratigraphic Unit III (including Subunits IIIa and IIIb) may correspond to beds of silty sand (see "Lithostratigraphy"). NGR values increase abruptly at the Subunit IIIb/IVa boundary to the maximum values ( $17 \mathrm{cps})$ observed in Hole M0064A. Lithostratigraphic Unit IV is characterized by relatively constant NGR values of $\sim 10 \mathrm{cps}$, except for lithostratigraphic Subunit IVb, which exhibits several intervals of reduced NGR $(\sim 5-10 \mathrm{cps})$.

\section{Shipboard magnetic susceptibility}

Magnetic susceptibility increases through lithostratigraphic Units I and II and is relatively constant in lithostratigraphic Subunit IIIa (Fig. F11). Lithostratigraphic Subunit IIIb is characterized by a slight increasing trend. Magnetic susceptibility increases sharply at the lithostratigraphic Subunit IIIb/IVa boundary, reflecting a lithologic change from clay and silty clay to diamicton (see "Lithostratigraphy"). Magnetic susceptibility is relatively constant in lithostratigraphic Unit IV, except for a large excursion visible at $\sim 13$ mbsf (Subunit IVa) and another increase that occurs at the Subunit IVa/IVb boundary.

\section{Color reflectance}

Lithostratigraphic Units I, II, and III are distinguished by differing color reflectance trends that are most apparent in the $b^{*}$ parameter (Fig. F11). In 
Units I and II, $\mathrm{b}^{*}$ exhibits a decreasing trend (more blue) from the top of the hole to $\sim 1.3 \mathrm{mbsf}$, where values abruptly increase at the Unit II/Subunit IIIa boundary. Values for $b^{*}$ are relatively high (more yellow) in the upper interval of lithostratigraphic Subunit IIIa and then decrease at $\sim 5$ mbsf and increase again at $\sim 6-6.6 \mathrm{mbsf}$ to the highest values observed in Hole M0064A. At the Subunit IIIa/IIIb boundary, $b^{*}$ values decrease abruptly. In Subunit IIIb and the uppermost interval of Subunit IVa, $b^{*}$ values exhibit a decreasing trend. From $\sim 16$ mbsf to the bottom of the hole, $\mathrm{b}^{*}$ exhibits a modal value of $\sim 5$.

\section{Density and $P$-wave velocity}

Dry density is generally low $\left(<1 \mathrm{~g} / \mathrm{cm}^{3}\right)$ in Units I and II and Subunit IIIa, with a positive excursion near the Subunit IIIa/IIIb boundary (Fig. F11). Values in Subunit IIIb increase to $\sim 2 \mathrm{~g} / \mathrm{cm}^{3}$. At the Subunit IIIb/ IVa boundary, dry density decreases again $\left(<1 \mathrm{~g} / \mathrm{cm}^{3}\right)$ and then increases in the lower interval of Subunit IVa (to $\sim 2 \mathrm{~g} / \mathrm{cm}^{3}$ ). Dry density remains relatively constant through the bottom part of Hole M0064A.

Gamma density and $P$-wave velocity were both measured at $2 \mathrm{~cm}$ intervals during the offshore phase of Expedition 347 (Fig. F12). Gamma density values measured on the multisensor core logger (MSCL) are moderately well correlated with the discrete bulk density measurements performed during the OSP $\left(r^{2}\right.$ $=0.5$; Fig. F12). The shipboard $P$-wave velocity is not well correlated with the discrete $P$-wave measurements performed during the OSP $\left(r^{2}=0.34\right.$; Fig. F12).

\section{Paleomagnetism}

Magnetic susceptibility measurements and simplified analyses of the natural remanent magnetization (NRM) were made on discrete specimens of known volume and mass (see "Paleomagnetism" in the "Methods" chapter [Andrén et al., 2015]). A total of 41 discrete samples were taken from Holes M0064A (16 samples), M0064C (14 samples), and M0064D (11 samples) at intervals of 25 and $50 \mathrm{~cm}$. The magnetic properties of this relatively small sample population varied. Magnetic susceptibility $(\chi)$ is relatively uniform between 8 and 2 mbsf, comprising Subunits IIIb (top) and IIIa and Units II and I. From $\sim 8$ to $\sim 12$ mbsf, $\chi$ ranges between $\sim 0.024 \times 10^{-6} \mathrm{~m}^{3} / \mathrm{kg}$ and 0.39 $\times 10^{-6} \mathrm{~m}^{3} / \mathrm{kg}$ within Subunits IVa and IIIb. The intensity of the NRM also varied over several orders of magnitude, from a maximum of $59 \mathrm{~A} / \mathrm{m}$ at $\sim 9.5 \mathrm{mbsf}$ in Subunit IIIb to $0.02 \times 10^{-3} \mathrm{~A} / \mathrm{m}$ in the top part of Subunit IVa. There was also considerable variation in the lower part of Subunit IVa, the top part of Subunit IVa, and Subunits IIIa and IIIb, with enhanced NRM intensities associated with laminated clay, silt clays, and dark greenish gray sandy silt subunits.

Paleomagnetic pilot samples were grouped into two categories according to their response to alternating field (AF) demagnetization. Category 1, containing samples from Subunit IVa (clast-rich stratified muddy diamicton and sandy gravel), has unstable magnetizations. Category 2, associated with Subunit IIIa, has a stable magnetic remanence but inclinations that differ between Hole M0064A (shallow) and Hole M0064C (steep).

\section{Discrete sample measurements}

A total of 41 discrete paleomagnetic samples were obtained from Holes M0064A, M0064C, and M0064D at 25 and $50 \mathrm{~cm}$ intervals.

\section{Magnetic susceptibility}

The results of the magnetic analyses are shown in Figure F13. Magnetic susceptibility $(\chi)$ ranges between $\sim 0.024 \times 10^{-6} \mathrm{~m}^{3} / \mathrm{kg}$ and $0.39 \times 10^{-6} \mathrm{~m}^{3} / \mathrm{kg}$, and a general declining trend in $\chi$ is evident from Unit II to the top of Subunit IVa, which appears to be positively related to a decrease in sample wet density. The intensity of the NRM, however, displays a wide range over 3 orders of magnitude, suggesting variable magnetic mineralogy and/or efficiency of recording of the geomagnetic field. Only one sample was recovered from Subunit IVb (massive clast-poor sandy diamicton), and it has an intermediate $\chi$ value close to $0.2 \times 10^{-6} \mathrm{~m}^{3} / \mathrm{kg}$. The top of Subunit IVa has the lowest $\chi$ values of the entire core sampled. There are several samples in the top of Subunits IVa and IIIb that have significantly higher $\chi$ than the background level for these units, which is between $0.01 \times$ $10^{-6}$ and $0.2 \times 10^{-6} \mathrm{~m}^{3} / \mathrm{kg}$, showing values between $0.3 \times 10^{-6}$ and $0.8 \times 10^{-6} \mathrm{~m}^{3} / \mathrm{kg}$.

\section{Natural remanent magnetization and its stability}

The NRM intensity spans 3 orders magnitude, between $0.02 \times 10^{-3} \mathrm{~A} / \mathrm{m}$ and $59 \times 10^{-3} \mathrm{~A} / \mathrm{m}$. The NRM intensity displays a weak positive relationship with $\chi$ in Subunits IVa and IIIb; however, this relationship is disturbed by the occurrence of samples with relatively high NRM intensity compared to $\chi$. Only two categories of response to AF demagnetization were observed in the pilot samples (Fig. F14). The pilot sample taken from Subunit IVb at $\sim 27.03$ meters composite depth (mcd) (Category 2), which contains a massive clast-poor sandy diamicton, displays a linear orthogonal vector that trends toward the origin during AF demagnetization, and the carrier(s) of remanence have medium to low coercivity with a re- 
sidual NRM intensity of $\sim 10 \%$ after the treatment at $40 \mathrm{mT}$. Category 2 has relatively high inclinations, between $70^{\circ}$ and $80^{\circ}$. Category 1 samples do not contain a stable magnetic remanence.

\section{Paleomagnetic directions}

Core sections recovered from Holes M0064A, M0064C, and M0064D are characterized by scattered inclination data and between-hole differences, such as the systematic $45^{\circ}$ difference between Hole M0064C and Hole M0064D between 10 and 5 mbsf. We conclude that the geomagnetic field has not been recorded sufficiently well at this site to allow the data to be used for relative paleomagnetic dating.

\section{Stratigraphic correlation}

Four holes were drilled at Site M0064: Holes M0064A (41.5 mbsf), M0064B (10.2 mbsf), M0064C (45.10 mbsf), and M0064D (41.20 mbsf). The meters composite depth scale for Site M0064 was based on correlation of magnetic susceptibility and natural gamma between holes (Fig. F15). At this site, the offset and overlap between adjacent holes was monitored (using data from every other core) by measuring Fast-track magnetic susceptibility (see "Physical properties") during the drilling process. These data proved to be an efficient tool to monitor and adjust the drilling process to maximize composite core recovery. Sediment cores were also logged with a standard MSCL to enable more precise hole-to-hole correlation and to construct a composite section for Site M0064 (Fig. F15). Before analysis, all magnetic susceptibility data were cleaned, removing any outliers from the measurements from the top of each section. The correlation was checked against scanned core slab images and lithologic descriptions. The depth offsets that define the composite section for Site M0064 are given in Table T6 (affine table).

Correlation between the magnetic susceptibility data in Holes M0064A, M0064B, M0064C, and M0064D is good, enabling the production of a continuous splice record for this site (Table T7). The accuracy of the correlation was visually checked from scanned core slab images using Corelyzer software. At Site M0064, correlation was straightforward to $11.54 \mathrm{mcd}$ (Section 347-M0064C-3H-3, $41 \mathrm{~cm}$ ). The lowermost part of Hole M0064C was appended in the splice record. No compression or expansion corrections were applied to the data, so the offset within each core was equal for all points. Thus, it is possible that some features are not similarly aligned between holes.

\section{Seismic units}

Seismic sequence boundary-sediment core-MSCL log (magnetic susceptibility) correlations are shown in Figure F16. Correlation is based on the integration of seismic data and lithostratigraphy (see "Lithostratigraphy"). Two-way traveltime values were calculated for each lithostratigraphic unit boundary using sound velocity values measured during the OSP (see "Physical properties"; Table T8). Lithostratigraphic unit boundaries were examined at these calculated two-way traveltime values to define the extent of agreement between seismic boundaries and actual lithologic and/or physical property disconformable surfaces. Uncertainties in the time-depth function and the effects of gas-saturated sediments could have resulted in inconsistencies between seismic features, sedimentological observations from cores, and MSCL logs.

\section{Seismic Unit I}

Two-way traveltime: $0.0829 \mathrm{~ms}$

Lithology: very dark greenish gray diatom-bearing clay (lithostratigraphic Unit I)

Depths: 0-0.33 mbsf (M0064A), 0-1.34 mbsf (M0064D)

Unit I corresponds to a thin, relatively transparent unit in the uppermost part of the seismic profile.

\section{Seismic Unit II}

Two-way traveltime: $0.0835 \mathrm{~ms}$

Lithology: greenish gray to very dark greenish gray sandy silt

Depths: 0.33-0.6 mbsf (M0064A), 1.34-1.75 mbsf (M0064D)

Unit II coincides with the uppermost strong reflector visible in the seismic profile. Magnetic susceptibility values are low in both Units I and II.

\section{Seismic Unit III}

Two-way traveltime: $0.0938 \mathrm{~ms}$

Lithology: dark grayish brown laminated clay and silty clay with dispersed clasts (lithostratigraphic Subunits IIIa and IIIb)

Depths: 0.6-8.53 mbsf (M0064A), 0-4.6 mbsf (M0064B), 0-7.29 mbsf (M0064C), 1.75-9.3 mbsf (M0064D)

Seismic Unit III shows a slightly irregular internal structure and a strong reflector at its base. Magnetic susceptibility values are relatively low and comparatively stable throughout this unit. However, they in- 
crease rapidly downcore at the lower boundary of Unit III.

\section{Seismic Unit IV}

\section{Seismic Subunit IVa}

Two-way traveltime: $0.1116 \mathrm{~ms}$

Lithology: stratified muddy diamicton and sandy gravel (lithostratigraphic Subunit IVa)

Depths: 8.53-26.5 mbsf (M0064A), 4.6-10.2 mbsf (M0064B), 7.29-25.7 mbsf (M0064C), 9.3-25.4 mbsf (M0064D)

Subunit IVa correlates relatively well with strong irregular reflectors visible in the seismic profile. Magnetic susceptibility values increase rapidly at the upper boundary of Subunit IVa and remain, with some variability, relatively high. The seismic profile shows strong parallel structures in the lowermost part of this unit, suggesting a possible unconformity or erosional contact between Subunits IVa and IVb.

\section{Seismic Subunit IVb}

Two-way traveltime: $0.1241 \mathrm{~ms}$

Lithology: primarily massive diamicton, possible shear fabrics (lithostratigraphic Subunit IVb)

Depths: 26.5-36.35 mbsf (M0064A), 25.7-36.7 mbsf (M0064C), 25.4-41.20 mbsf (M0064D)

Magnetic susceptibility values are slightly lower in Subunit IVb than in Subunit IVa. The seismic profile of Subunit IVb shows faint irregular structures that are slightly stronger and clearer than in the following subunit.

\section{Seismic Subunit IVc}

Two-way traveltime: $0.1332 \mathrm{~ms}$

Lithology: stratified sandy clayey silt with dispersed clasts and diamicton (lithostratigraphic Subunit IVc)

Depths: 36.35-41.5 mbsf (M0064A), 36.7-45.0 mbsf (M0064C)

This unit is followed by sedimentary bedrock based on the seismic profile.

\section{Downhole measurements}

\section{Logging operations}

Hole M0064A was drilled to $41.5 \mathrm{~m}$ drilling depth below seafloor (DSF). In preparation for logging, the hole was circulated with seawater and the drill string was pulled back in the hole to $2 \mathrm{~m}$ wireline log depth below seafloor (WSF). Logging operations started in Hole M0064A with rigging up of the Weatherford logging setup.
Before the running in the hole of the first tool string could be started, a problem with the winch was noticed. After the problem was fixed, the gamma ray tool (MCG)/array induction tool (MAI) tool string, measuring total gamma ray and induction, could be run in the hole, and a downlog was started. The seafloor was picked up by the gamma ray, and the tool string came out of the pipe. Immediately, a sudden drop in tension indicated that the tool string set up at $\sim 5 \mathrm{~m}$ WSF. Logging operations were abandoned in this hole after this unsuccessful attempt. During rigup of the logging setup, the pipe was completely out of the hole, probably causing the top of the hole to collapse.

Downhole logging measurements in Hole M0064D were performed after completion of coring to a total depth of $41.2 \mathrm{~m}$ DSF. In preparation for logging, the hole was circulated with seawater and the pipe was pulled back to $\sim 7.6 \mathrm{~m}$ WSF.

For downhole logging in Hole M0064D, two tool strings were deployed:

- MCG/MAI tool string, measuring natural gamma ray and electrical resistivity; and

- MCG/spectral gamma ray tool (SGS) tool string, measuring total gamma ray and spectral gamma ray.

The MCG/MAI tool string was lowered and downlogged to $31 \mathrm{~m}$ WSF. The hole was then uplogged to the seafloor. The wireline depth to the seafloor was determined from the step increase in gamma ray values.

After this, the MCG/SGS tool string was lowered and reached $26.4 \mathrm{~m}$ WSF while downlogging. The hole was then uplogged to the seafloor. The tools provided continuous and good quality log data.

\section{Logging units}

Hole M0064D is divided into three units on the basis of the logs (Fig. F17). The uplog was used as the reference to establish the wireline log depth below seafloor depth scale.

\section{Logging Unit 1: base of drill pipe to14.7 m WSF}

Natural gamma ray in this logging unit generally increases with depth, with some fluctuations around 10 and $13 \mathrm{~m}$ WSF. The negative excursions that occur in this logging unit may correspond to the beds of silty sand described in lithostratigraphic Unit III (see "Lithostratigraphy"). At $14.7 \mathrm{~m}$ WSF is a sudden drop in NGR values. Resistivity slightly increases from 9 to $13 \mathrm{~m}$ WSF and then decreases to its lowest value at $15 \mathrm{~m}$ WSF. 


\section{Logging Unit 2: 14.7-21 m WSF}

After the drop in NGR at $15 \mathrm{~m}$ WSF, natural gamma ray remains constant in logging Unit 2, with a slight increase at the bottom of the unit. Thorium values are higher in logging Unit 2 than in logging Unit 1, with large fluctuations around $20 \mathrm{~m}$ WSF. Resistivity increases with depth in logging Unit 2 because of compaction.

\section{Logging Unit 3: 21-31 m WSF}

Deeper than $21 \mathrm{~m}$ WSF, the resistivity log shows constant values. The natural gamma ray log shows a slight decrease but a different trend for the different tool strings used. Total gamma ray measured with the MCG/MAI tool string is 20 gAPI lower than the one measured with the MCG/SGS tool string. This may be due to changing borehole conditions.

\section{References}

Andrén, E., Andrén, T., and Kunzendorf, H., 2000. Holocene history of the Baltic Sea as a background for assess- ing records of human impact in the sediments of the Gotland Basin. Holocene, 10(6):687-702. doi:10.1191/ 09596830094944

Andrén, T., Jørgensen, B.B., Cotterill, C., Green, S., Andrén, E., Ash, J., Bauersachs, T., Cragg, B., Fanget, A.-S., Fehr, A., Granoszewski, W., Groeneveld, J., Hardisty, D., Herrero-Bervera, E., Hyttinen, O., Jensen, J.B., Johnson, S., Kenzler, M., Kotilainen, A., Kotthoff, U., Marshall, I.P.G., Martin, E., Obrochta, S., Passchier, S., Quintana Krupinski, N., Riedinger, N., Slomp, C., Snowball, I., Stepanova, A., Strano, S., Torti, A., Warnock, J., Xiao, N., and Zhang, R., 2015. Methods. In Andrén, T., Jørgensen, B.B., Cotterill, C., Green, S., and the Expedition 347 Scientists, Proc. IODP, 347: College Station, TX (Integrated Ocean Drilling Program). doi:10.2204/

iodp.proc.347.102.2015

Powell, A.J. (Ed.), 1992. A Stratigraphic Index of Dinoflagellate Cysts: London (Springer).

Snoeijs, P., Vilbaste, S., Potapova, M., Kasperoviciene, J., and Balashova, J. (Eds.), 1993-1998. Intercalibration and Distribution of Diatom Species in the Baltic Sea (Vol. 1-5): Uppsala, Sweden (Opulus Press).

Publication: 20 February 2015

MS 347-108 
Figure F1. Graphic lithology log summary, Holes M0064A-M0064D.

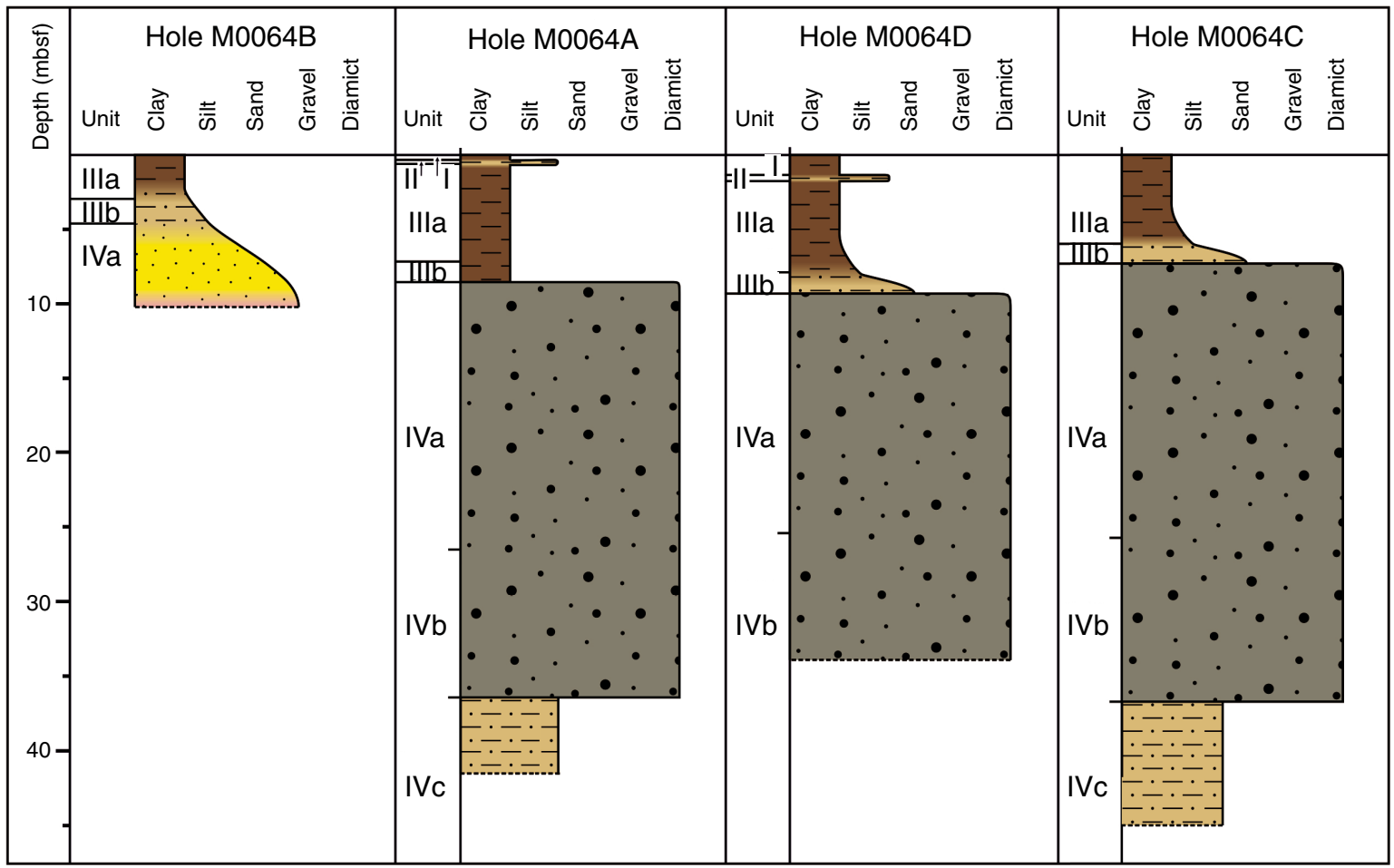


Figure F2. Graphic lithology log summary, Site M0064. Depths quoted represent boundary depths from Holes M0064D (Unit I to the base of Subunit IVa) and M0064C (from the top of Subunit IVb to the base of Subunit IVc).

\begin{tabular}{|c|c|c|c|c|c|c|c|c|c|c|c|}
\hline \multicolumn{12}{|c|}{ IODP Expedition 347 Site M0064 } \\
\hline $\begin{array}{l}\text { 등 } \\
\text { ㅇํㄹ }\end{array}$ & 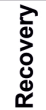 & Unit & $\frac{\widehat{\pi}}{0}$ & 素 & 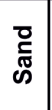 & 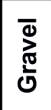 & 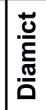 & Symbols & $\begin{array}{l}\frac{n}{0} \\
\frac{0}{0} \\
\frac{D}{U}\end{array}$ & Description & Interpretation \\
\hline 20. & & IVc & & & & & & $\frac{1}{\underline{\underline{I I I I}}}$ & : & 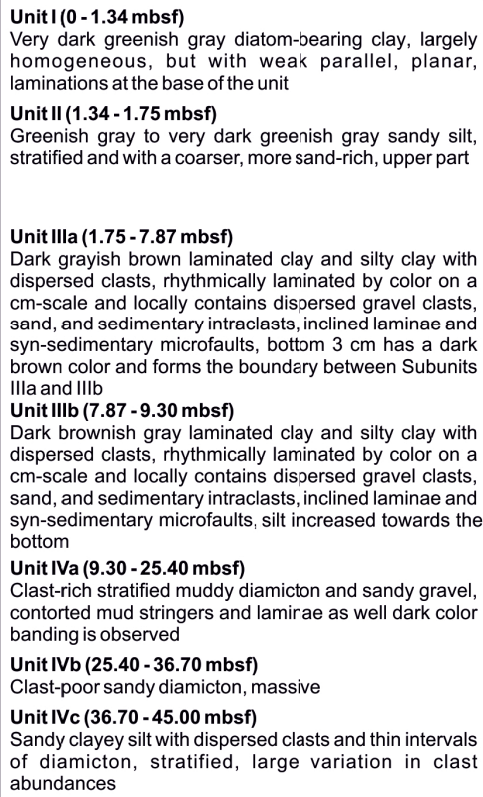 & $\begin{array}{l}\text { Unitl } \\
\text { Brackish marine or lake } \\
\text { environment with low terrigenous } \\
\text { sedimentinput } \\
\text { UnitII } \\
\text { Deposition in a shallow, oxic, } \\
\text { pro-glacial lake environment with } \\
\text { relatively high terrigenous } \\
\text { sedimentation rates } \\
\text { Unit III } \\
\text { Glacial lake environment with } \\
\text { minor slumping on an unstable } \\
\text { sloping environment or with high } \\
\text { sedimentation rates; outsized } \\
\text { gravel clasts probably represent } \\
\text { ice rafting } \\
\\
\\
\\
\text { Unit IV } \\
\text { Deposited in an ice-influenced } \\
\text { depositional environment (ice- } \\
\text { p r o x i m a I, sub g l a c i I I, } \\
\text { glaciomarine/glaciolacustrine } \\
\text { depostition environment) }\end{array}$ \\
\hline
\end{tabular}




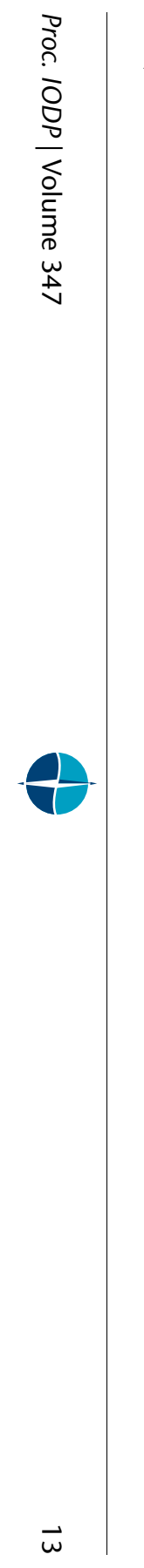

Figure F3. Line scan images of lithostratigraphic Units I-IV. The Unit I/II boundary is at $33 \mathrm{~cm}$ in the leftmost image from Core 347-M0064D-1H. A. Units I and II. B. Unit III. C. Subunit IVa. D. Subunit IVb.

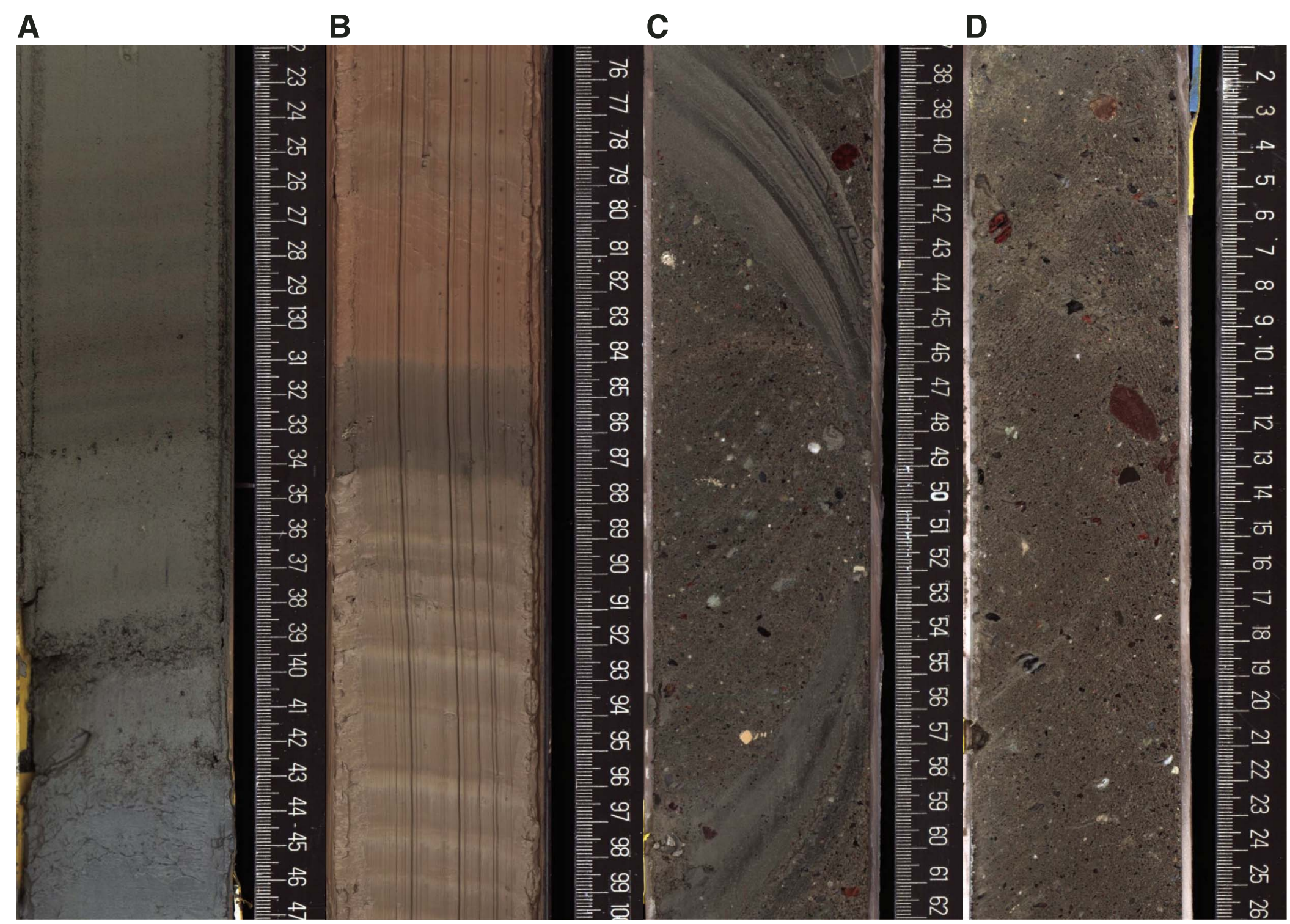


Figure F4. Three reworked organic-walled dinoflagellate cysts from Core 347-M0064A-12H. 1. Apectodinium. 2. Wetzeliella. 3. Charlesdowniea. Scale bars $=20 \mu \mathrm{m}$.
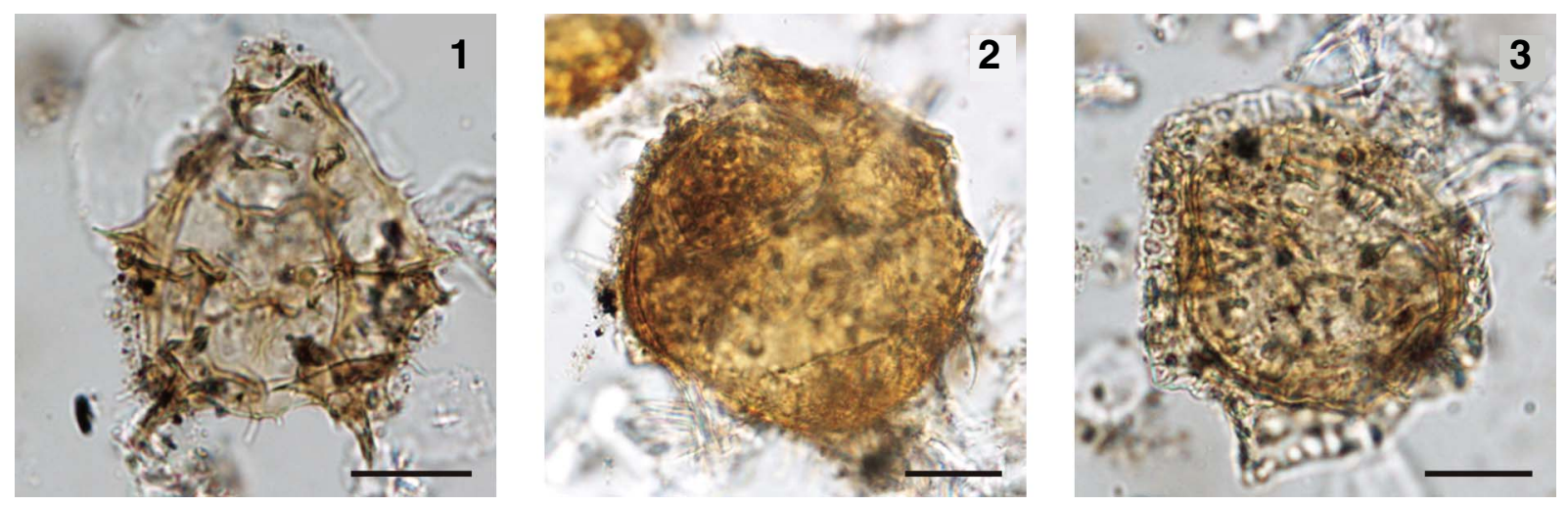
Figure F5. Concentrations of (A) chloride, (B) shipboard salinity calculated from refractive index, (C) chloride-based salinity, and (D) alkalinity in interstitial water samples, Site M0064.
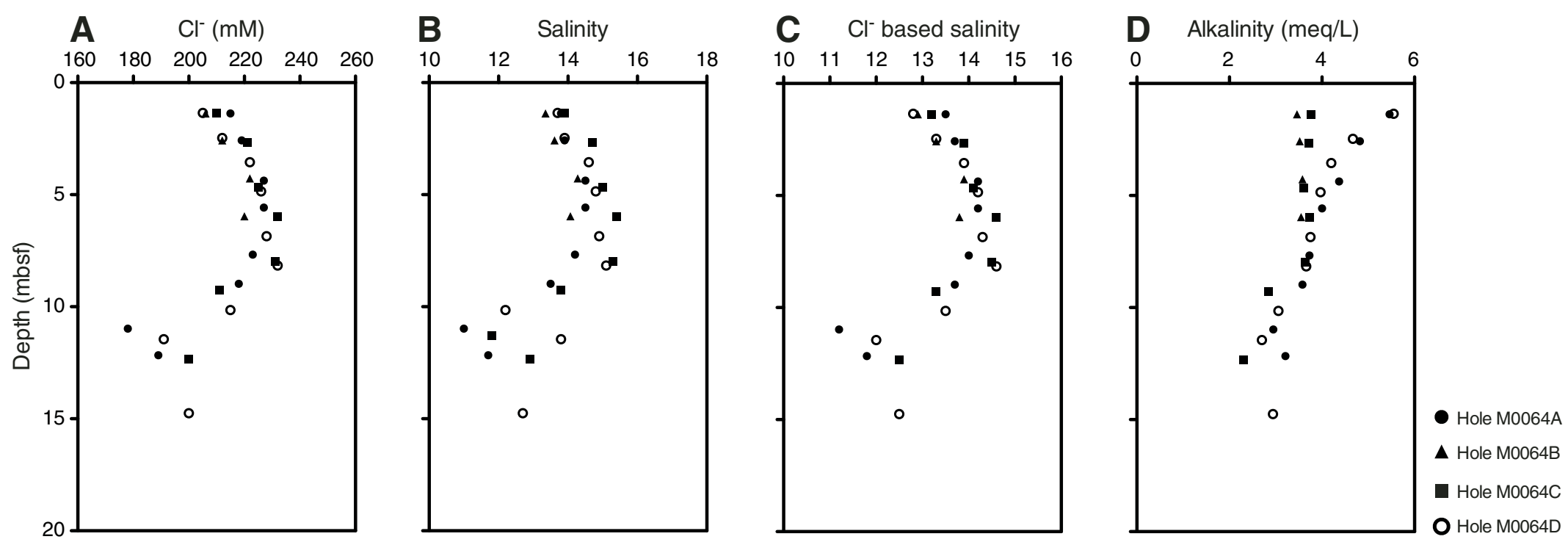
Figure F6. Concentrations and ratios of (A) sulfate, (B) sulfate/chloride, (C) ammonium, (D) phosphate, (E) iron, (F) manganese, and (G) pH from interstitial water samples, Site M0064. Dashed line = seawater ratio.
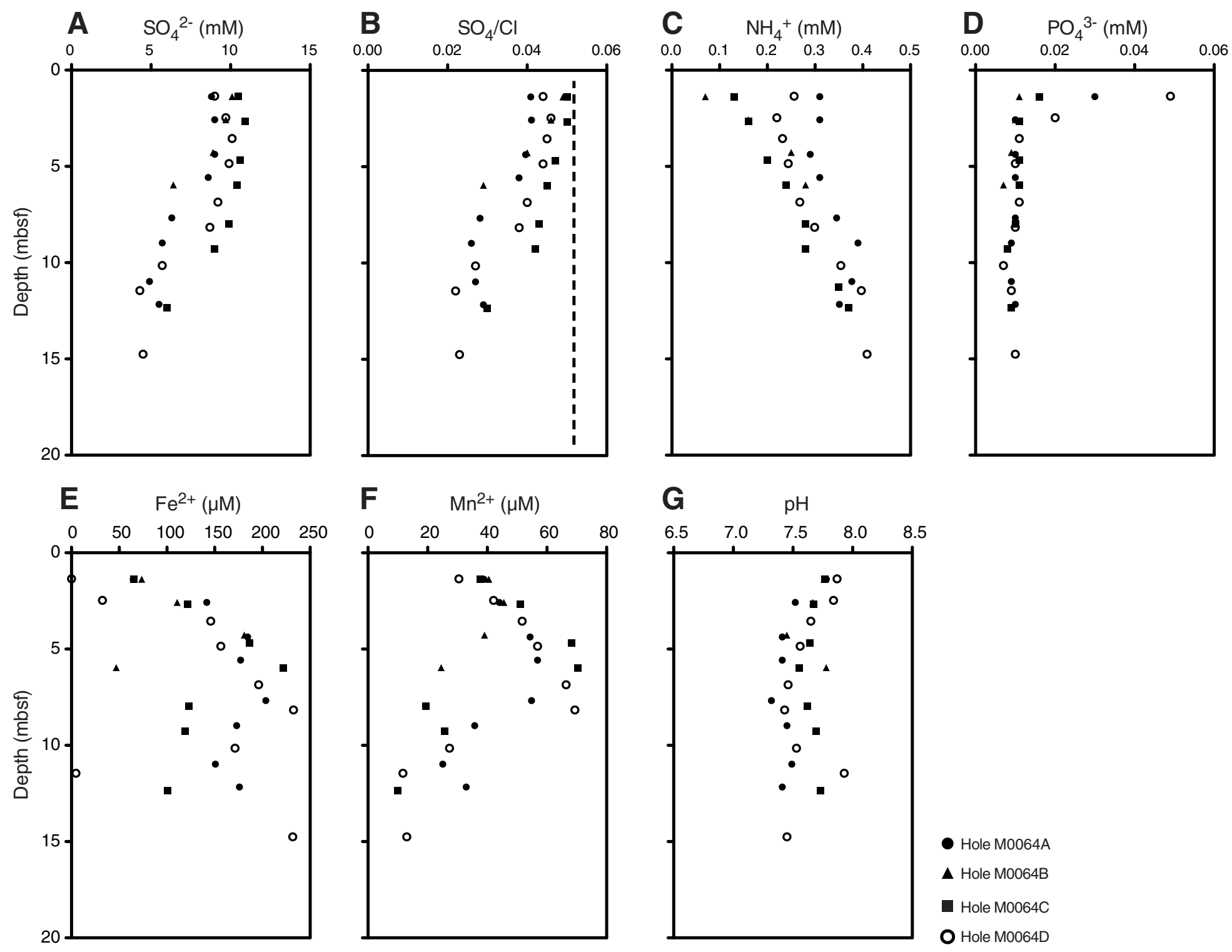
Figure F7. Concentrations and ratios of (A) bromide, (B) bromide/chloride, (C) boron, and (D) boron/chloride from interstitial water samples, Site M0064. Dashed lines = seawater ratio.
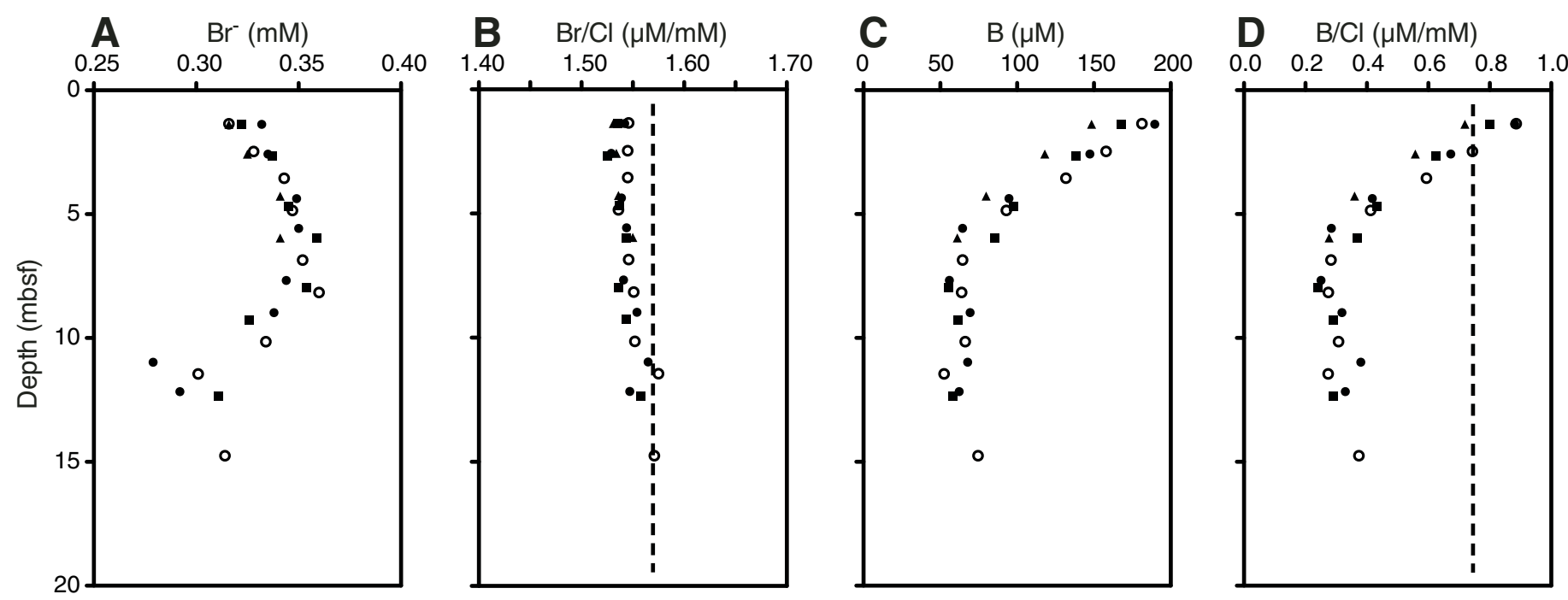

Hole M0064A

\ Hole M0064B

- Hole M0064C O Hole M0064D 
Figure F8. Concentrations and ratios of (A) sodium, (B) potassium, (C) magnesium, (D) calcium, (E) sodium/chloride, (F) potassium/chloride, (G) magnesium/chloride, and (H) calcium/chloride from interstitial water samples, Site M0064. Dashed lines = seawater ratio.

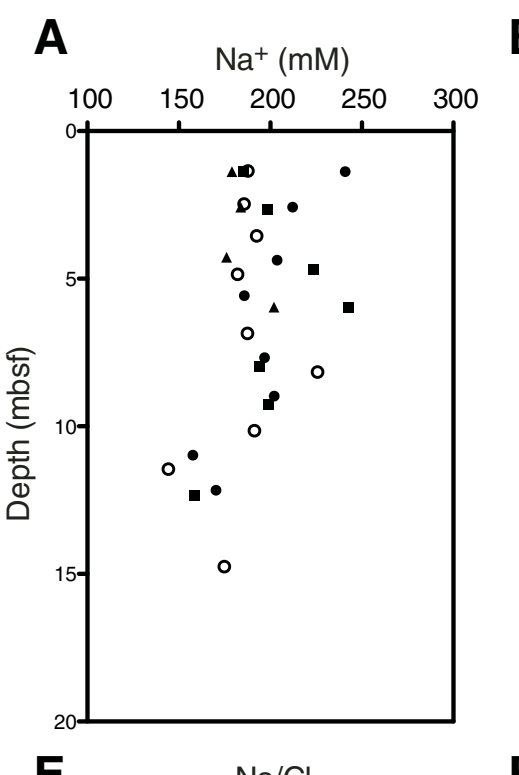

B

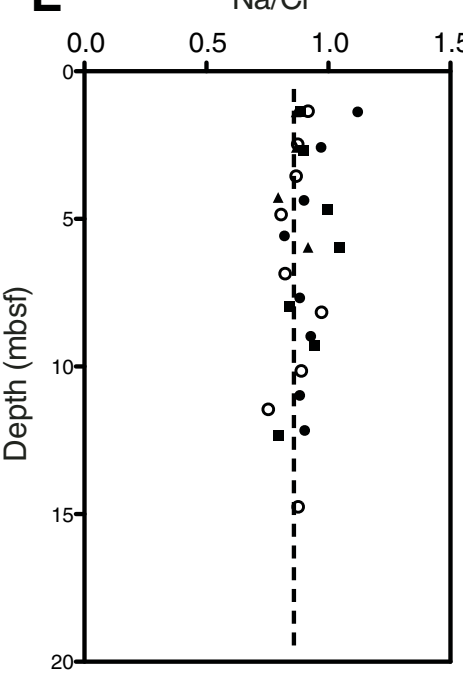

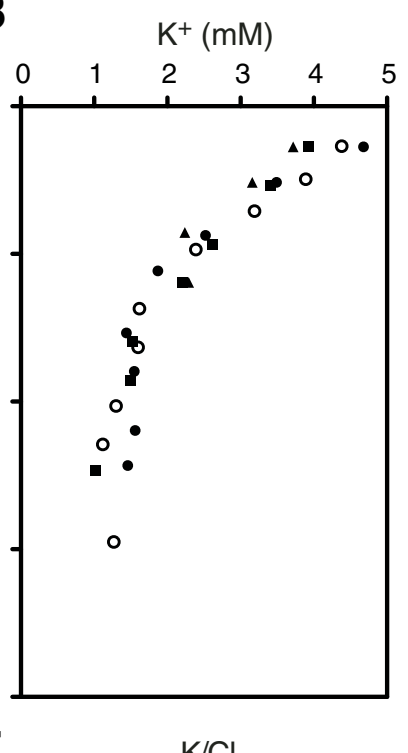

C
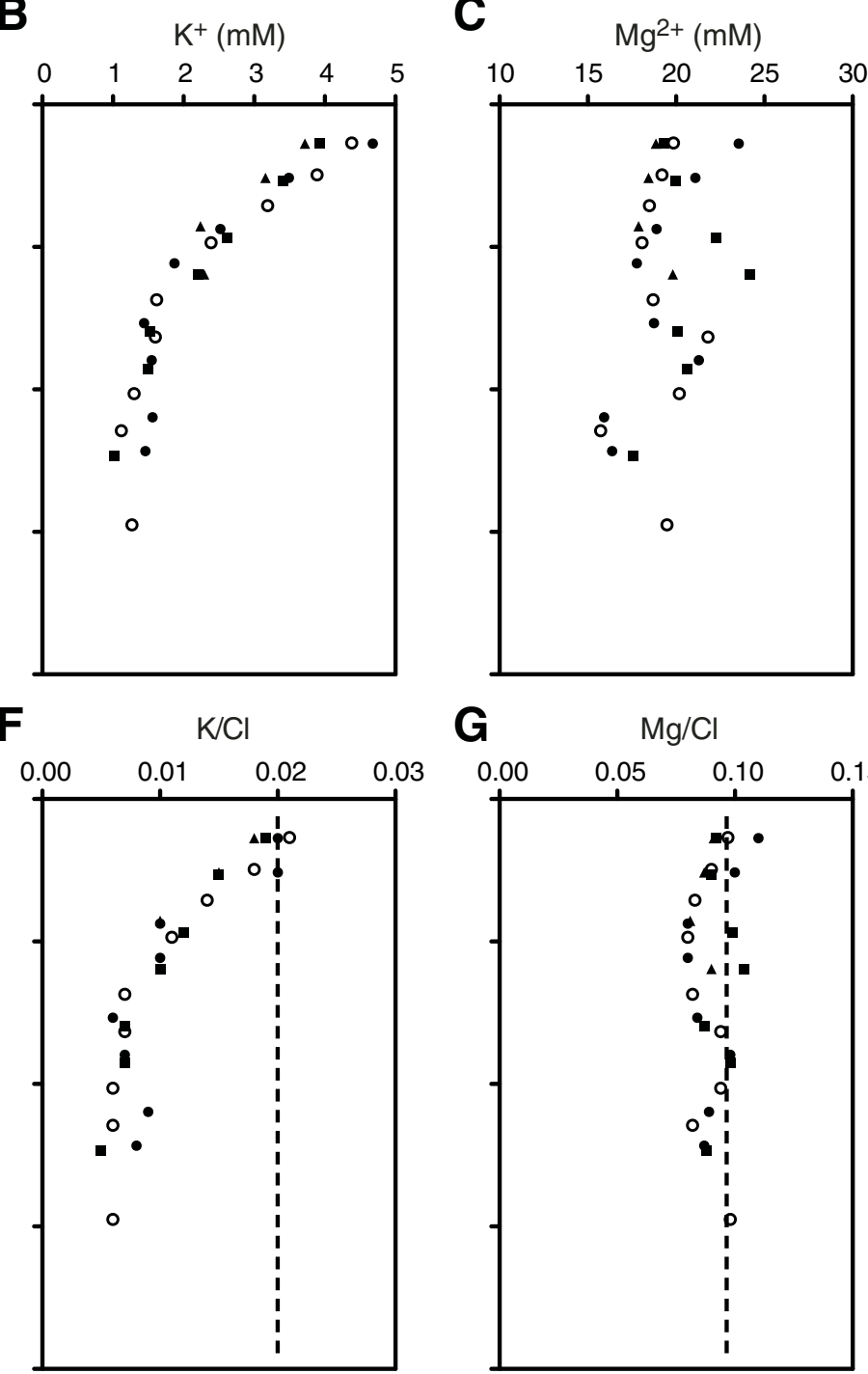
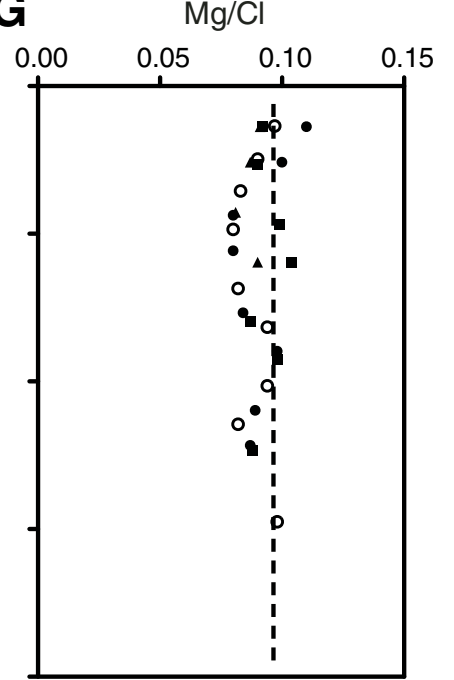

D
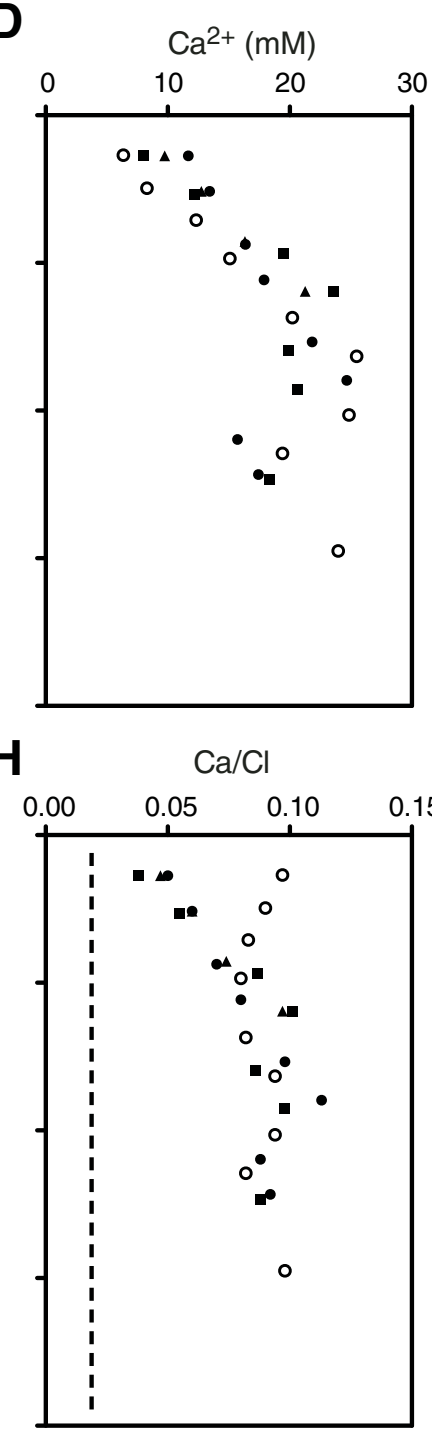

- Hole M0064A

$\Delta$ Hole M0064B

- Hole M0064C

O Hole M0064D 
Figure F9. Concentrations of (A) strontium, (B) lithium, (C) dissolved silica, and (D) barium from interstitial water samples, Site M0064.
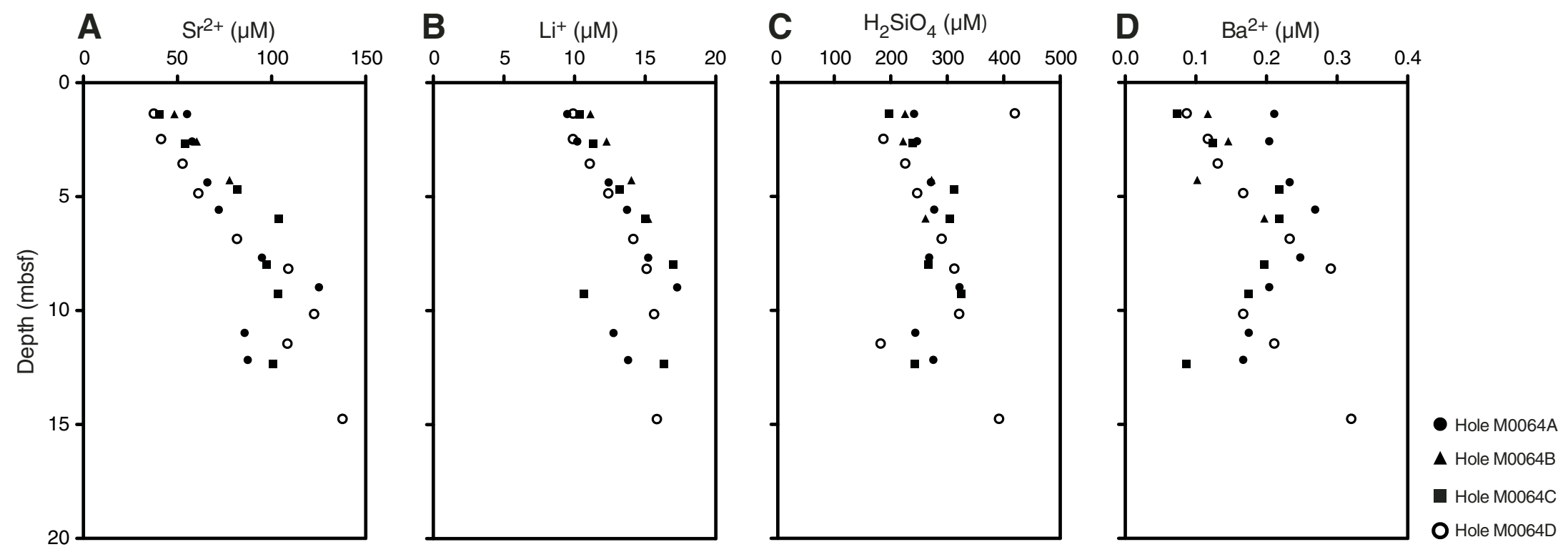
Figure F10. Sedimentary (A) total carbon (TC), (B) total organic carbon (TOC), (C) total inorganic carbon (TIC), and (D) total sulfur (TS) values, Site M0064.
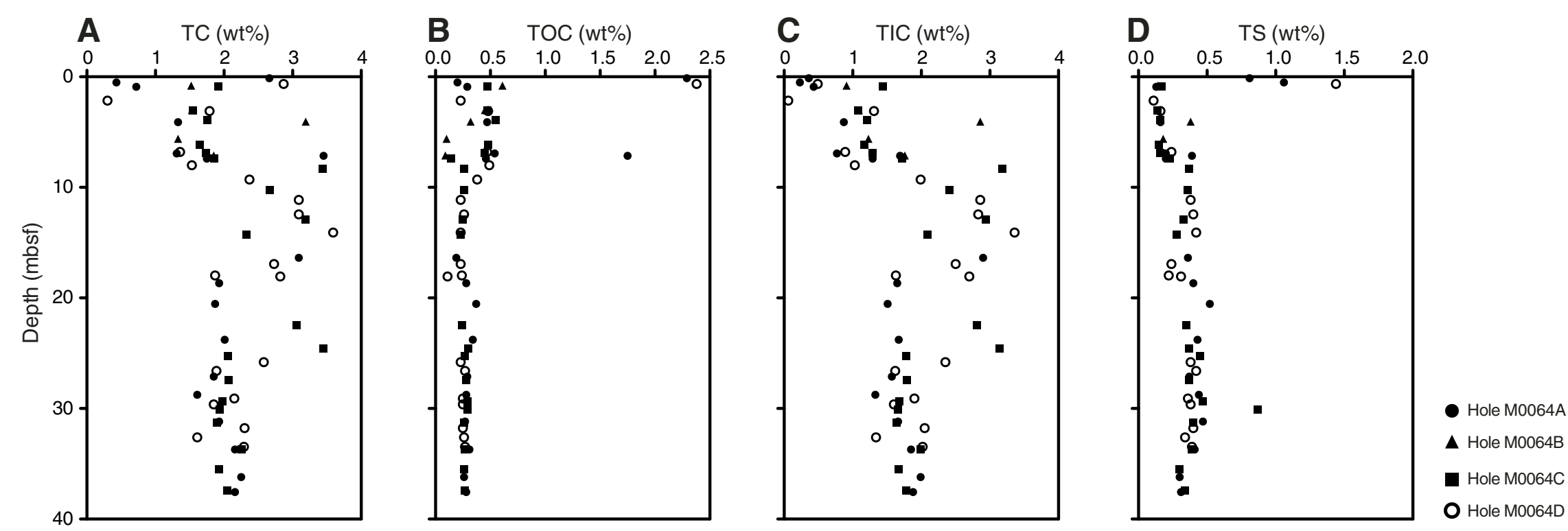
Figure F11. Natural gamma radiation (NGR) (cps), MSCL-measured magnetic susceptibility (MS) (10-5 SI), dry density $\left(\mathrm{g} / \mathrm{cm}^{3}\right)$, and color reflectance parameter $\mathrm{b}^{*}$, Hole M0064A.

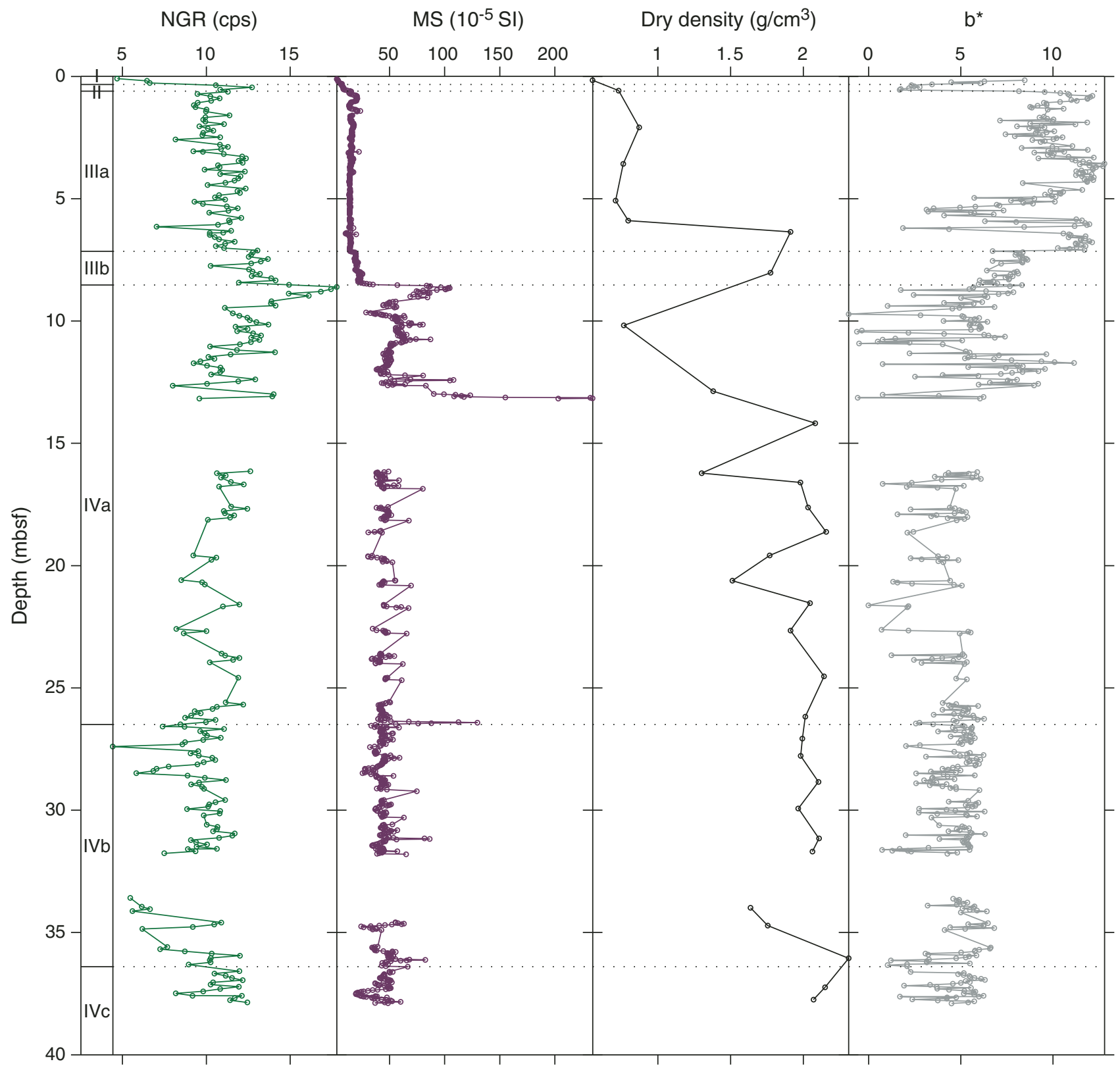


Figure F12. A. Gamma density $\left(\mathrm{g} / \mathrm{cm}^{3}\right)$ and discrete bulk density $\left(\mathrm{g} / \mathrm{cm}^{3}\right)$ measurements derived from pycnometer moisture and density analyses, Hole M0064A. B. Multisensor core logger (MSCL) $P$-wave and discrete velocity (m/s) measurements performed during the OSP, Hole M0064A.

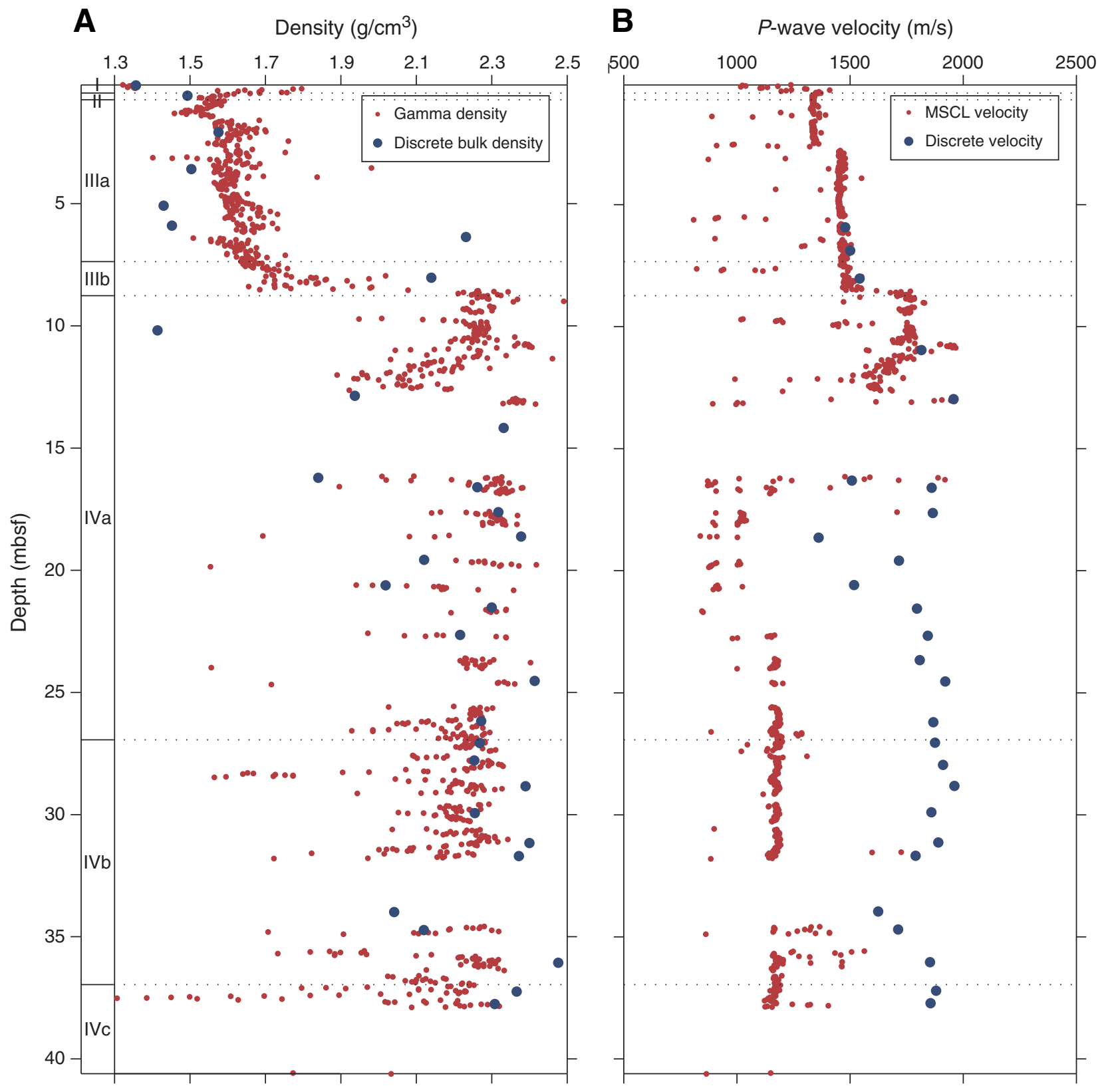


Figure F13. Plots and biplots of magnetic susceptibility $(\chi)$, natural remanent magnetization (NRM) intensity, and NRM inclination of discrete paleomagnetic samples, Hole M0064D. Dashed line = geocentric axial dipole $(\mathrm{GAD})$ prediction of inclination for the site latitude $\mathrm{AF}=\mathrm{alternating}$ field.
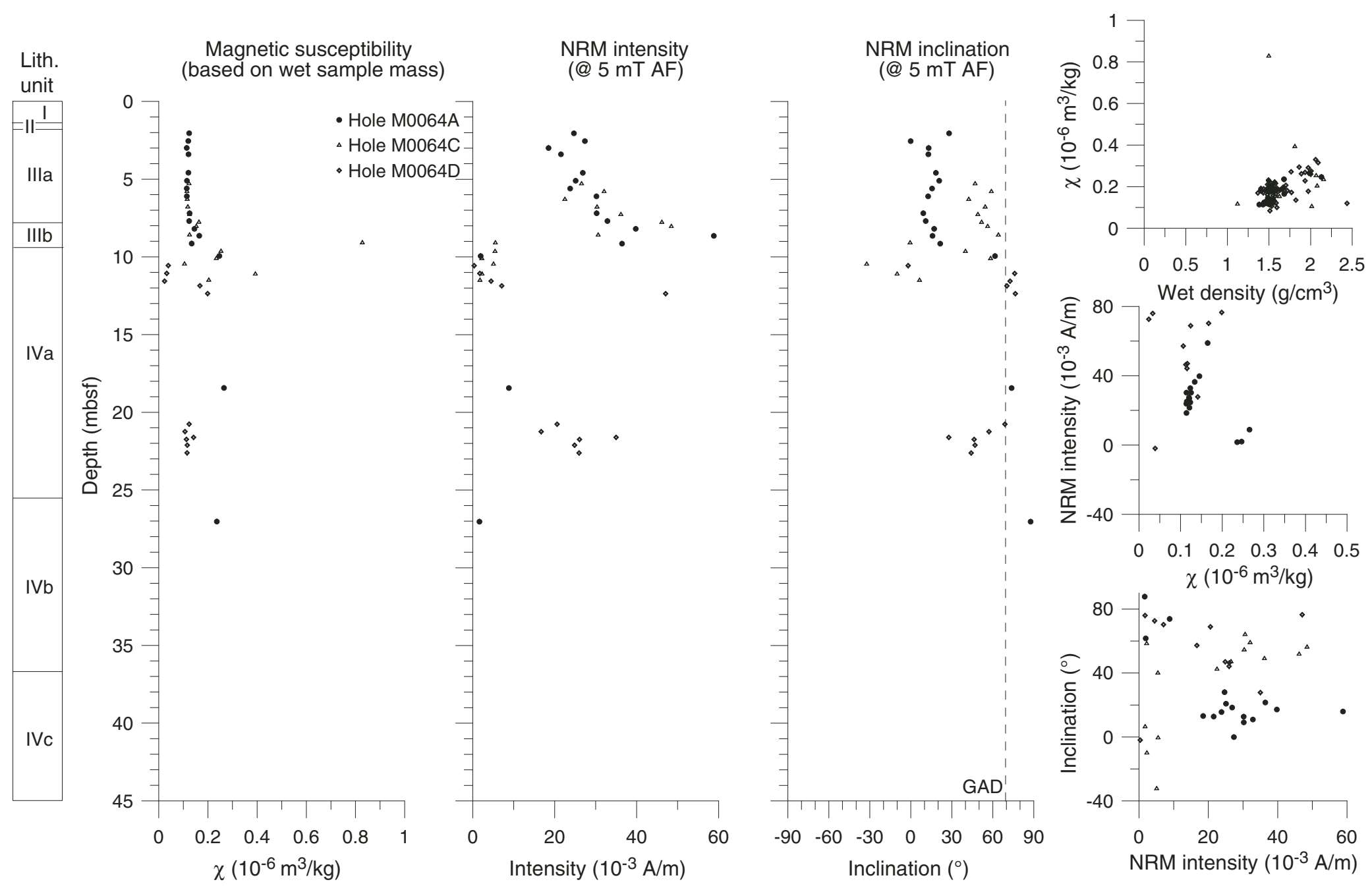

$\begin{array}{llllll}0 & 0.1 & 0.2 & 0.3 & 0.4 & 0.5\end{array}$

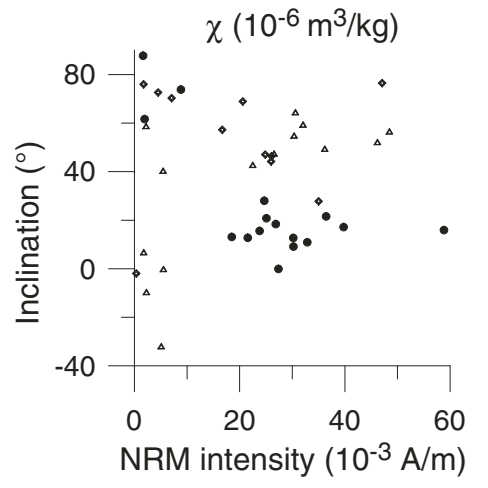


Figure F14. Plots of natural remanent magnetization (NRM) after alternating field (AF) demagnetization to 80 mT. A. Sample 347-M0064A-2H-2, 95 cm; 5.60 mbsf. B. Sample 347-M0064A-17H-1, 89 cm; 27.03 mbsf. Category 1 includes samples that do not contain a stable magnetization. Category 2 contains a vector that trends toward the origin during demagnetization. Open squares $=$ vertical, solid squares $=$ horizontal.
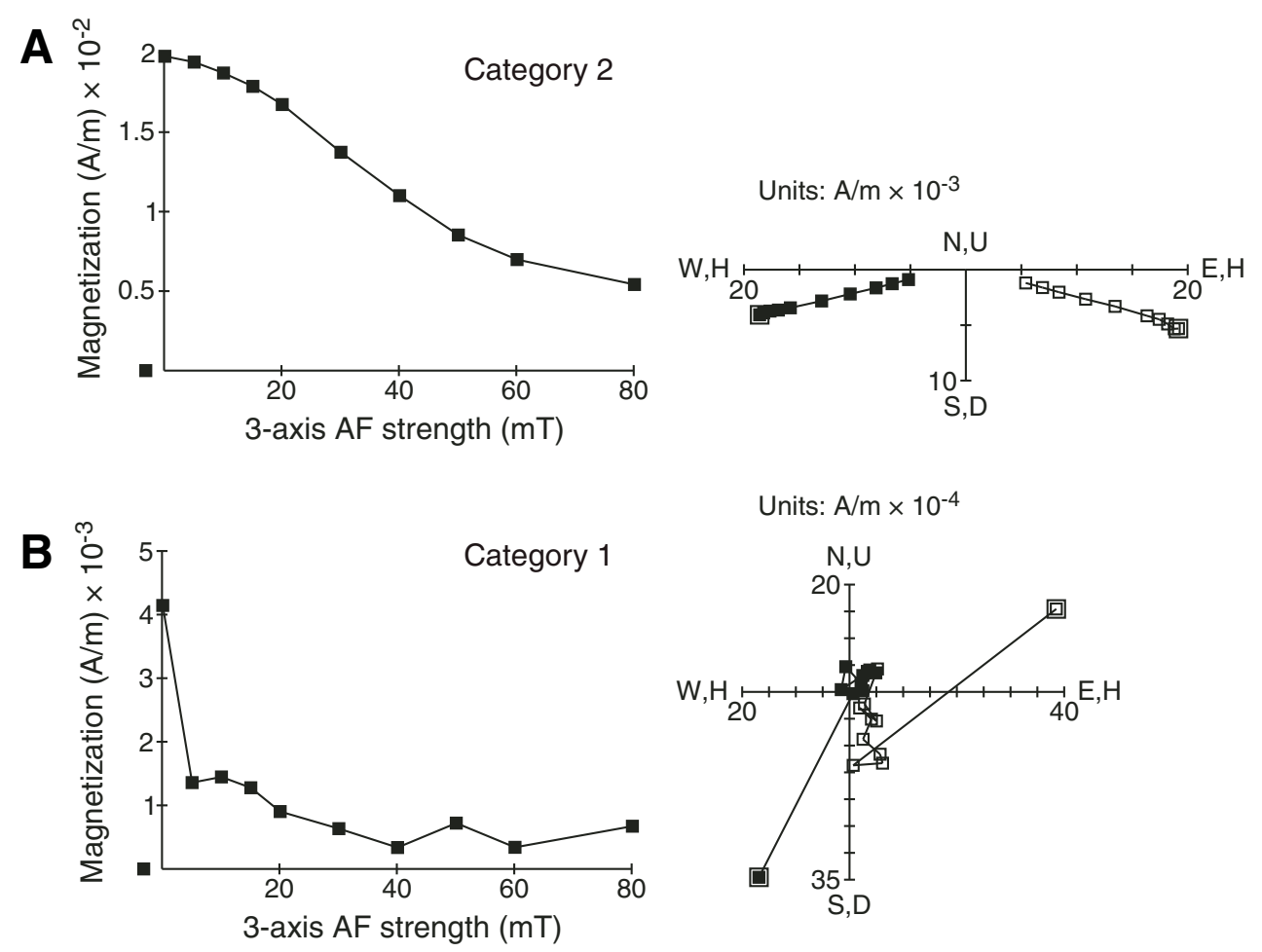

Units: $\mathrm{A} / \mathrm{m} \times 10^{-4}$

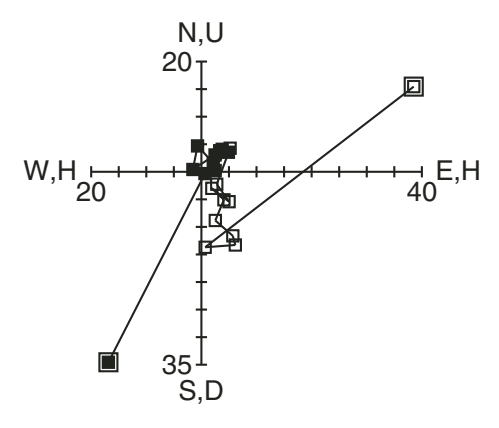



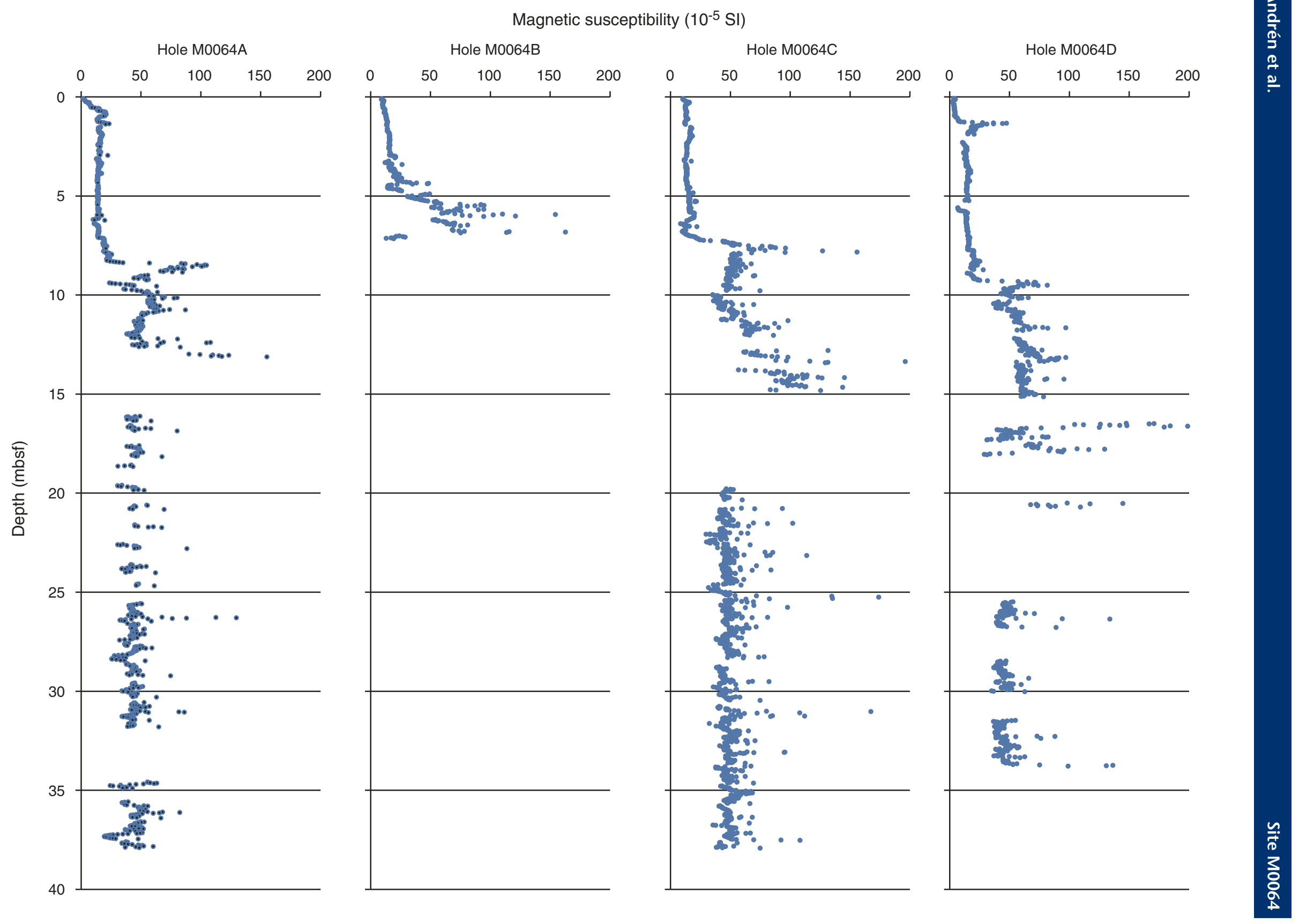
Figure F16. Correlation of the seismic profile with lithostratigraphic boundaries (seismic units and subunits) as well as multisensor core logger magnetic susceptibility data (Hole M0064A), Site M0064. SF = seafloor, BWT = bottom of Weichselian till, BR = bedrock.

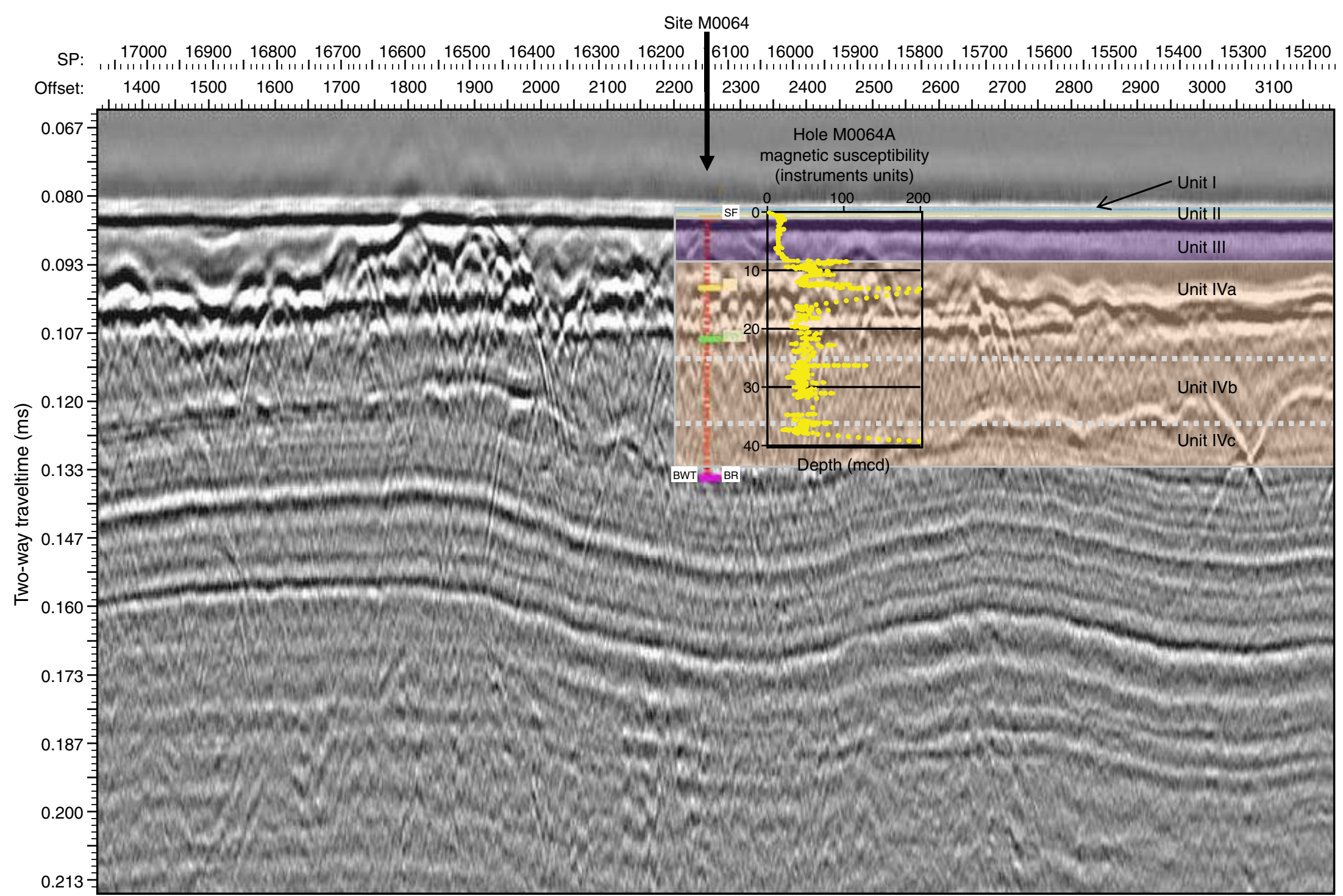


Figure F17. Gamma ray log, spectral gamma ray $\log$, and resistivity log, Hole M0064D. The pipe was set at 7.6 m WSF.

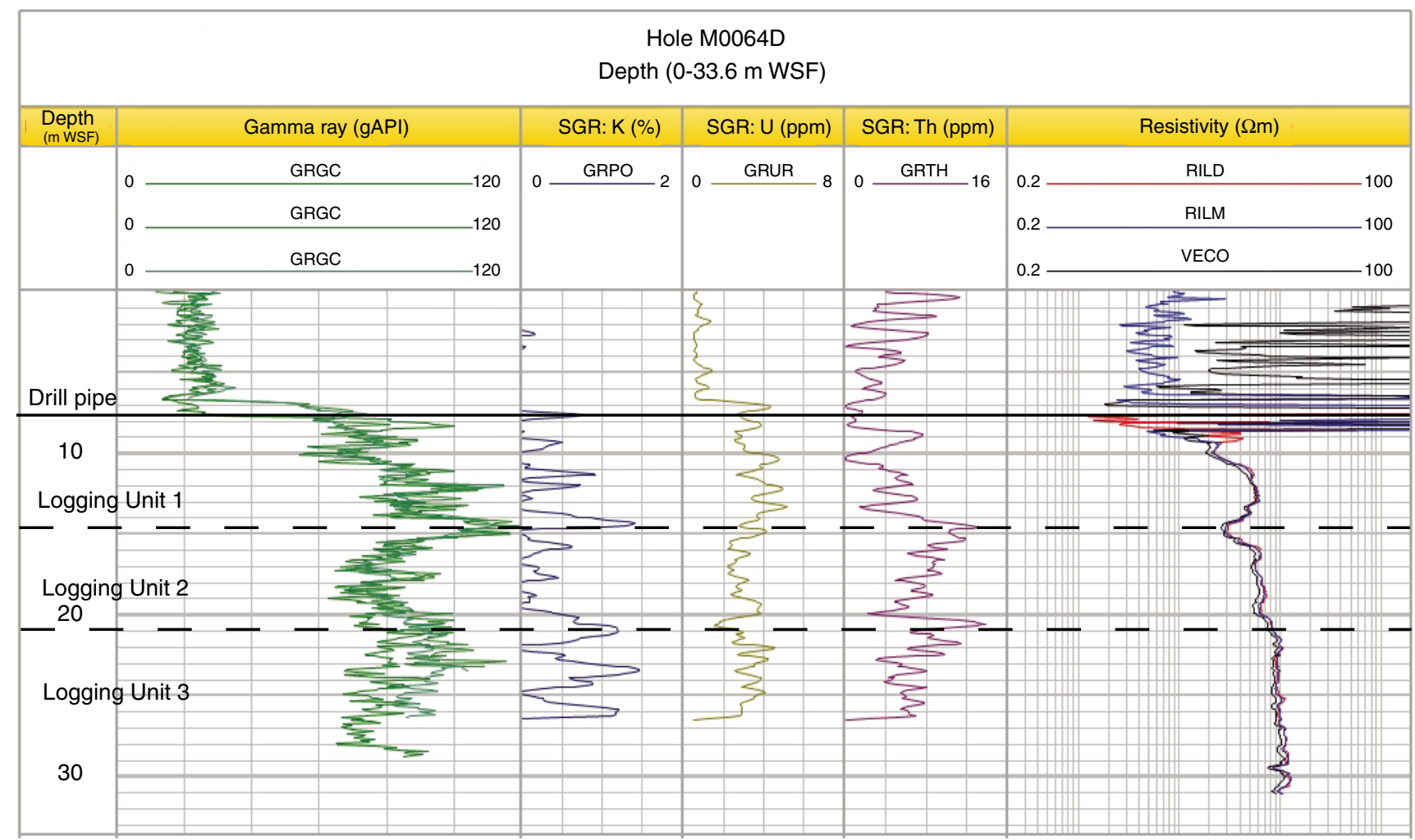


Table T1. Operations, Site M0064. (Continued on next two pages.)

\begin{tabular}{|c|c|c|c|c|c|c|c|c|c|}
\hline \multirow[b]{2}{*}{ Core } & \multirow{2}{*}{$\begin{array}{l}\text { Coring } \\
\text { method }\end{array}$} & \multirow{2}{*}{$\begin{array}{l}\text { Date } \\
(2013)\end{array}$} & \multirow{2}{*}{$\begin{array}{l}\text { Time } \\
\text { (UTC) }\end{array}$} & \multicolumn{2}{|c|}{ Depth (mbsf) } & \multirow{2}{*}{$\begin{array}{l}\text { Recovered } \\
(\mathrm{m})\end{array}$} & \multirow{2}{*}{$\begin{array}{l}\text { Recovery } \\
(\%)\end{array}$} & \multirow[b]{2}{*}{ Mud type } & \multirow[b]{2}{*}{ Comments } \\
\hline & & & & Top & Bottom & & & & \\
\hline \multicolumn{10}{|c|}{ 347-M0064A- } \\
\hline & & 20 Oct & 1200 & & & & & & On Site M0064, prepared for ROV survey of seabed \\
\hline & & 20 Oct & 1245 & & & & & & Lowered template and ROV into moonpool \\
\hline & & 20 Oct & 1415 & & & & & & ROV survey of Holes M0064A-M0064C completed, ROV back on deck \\
\hline & & 20 Oct & 1425 & & & & & & Repositioned over Hole M0064A \\
\hline $1 \mathrm{H}$ & PCS & 20 Oct & 1545 & 0.00 & 3.00 & 3.32 & 110.67 & Seawater & Fired from position calculated to be just above seabed \\
\hline $2 \mathrm{H}$ & PCS & 20 Oct & 1615 & 3.00 & 6.30 & 3.54 & 107.27 & Seawater & \\
\hline $3 \mathrm{H}$ & PCS & 20 Oct & 1715 & 6.30 & 9.60 & 3.54 & 107.27 & Seawater & \\
\hline $4 \mathrm{H}$ & PCS & 20 Oct & 1745 & 9.60 & 12.90 & 3.32 & 100.61 & Seawater & Till \\
\hline $5 \mathrm{~N}$ & NRCB & 20 Oct & 1845 & 12.90 & 15.90 & 0.60 & 20 & Seawater & \\
\hline $6 \mathrm{P}$ & PCA & 20 Oct & 2000 & 15.90 & 16.05 & 0.15 & 100 & Seawater & \\
\hline $7 \mathrm{~N}$ & NRCB & 20 Oct & 2020 & 16.05 & 16.50 & 0.68 & 151.11 & Guar & Basket catcher jammed with stones within till: removed for next run \\
\hline $8 \mathrm{~N}$ & NRCB & 20 Oct & 2115 & 16.50 & 17.50 & 0.53 & 53 & Guar & \\
\hline $9 \mathrm{~N}$ & NRCB & 20 Oct & 2210 & 17.50 & 18.50 & 0.77 & 77 & Guar & \\
\hline $10 \mathrm{~N}$ & NRCB & 20 Oct & 2310 & 18.50 & 19.50 & 0.23 & 23 & Guar & \\
\hline $11 \mathrm{~N}$ & NRCB & 20 Oct & 2345 & 19.50 & 20.50 & 0.44 & 44 & Guar & \\
\hline $12 \mathrm{~N}$ & NRCB & 21 Oct & 0043 & 20.50 & 21.50 & 0.39 & 39 & Guar & \\
\hline $13 \mathrm{~N}$ & NRCB & 21 Oct & 0117 & 21.50 & 22.50 & 0.31 & 31 & Guar & \\
\hline $14 \mathrm{~N}$ & NRCB & 21 Oct & 0148 & 22.50 & 23.50 & 0.37 & 37 & Guar & \\
\hline $15 \mathrm{~N}$ & NRCB & $21 \mathrm{Oct}$ & 0223 & 23.50 & 24.50 & 0.59 & 59 & Guar & \\
\hline $16 \mathrm{~N}$ & NRCB & $21 \mathrm{Oct}$ & 0249 & 24.50 & 25.50 & 0.25 & 25 & Guar & \\
\hline $17 \mathrm{~N}$ & NRCB & 21 Oct & 0320 & 25.50 & 26.50 & 1.16 & 116 & Guar & \\
\hline $18 \mathrm{~N}$ & NRCB & $21 \mathrm{Oct}$ & 0352 & 26.50 & 27.50 & 0.97 & 97 & Guar & \\
\hline $19 \mathrm{~N}$ & NRCB & $21 \mathrm{Oct}$ & 0440 & 27.50 & 28.50 & 1.14 & 114 & Guar & \\
\hline $20 \mathrm{~N}$ & NRCB & $21 \mathrm{Oct}$ & 0520 & 28.50 & 29.50 & 0.79 & 79 & Guar & \\
\hline $21 \mathrm{~N}$ & NRCB & 21 Oct & 0605 & 29.50 & 30.50 & 0.90 & 90 & Guar & \\
\hline $22 \mathrm{~N}$ & NRCB & 21 Oct & 0620 & 30.50 & 31.50 & 1.22 & 122 & Guar & \\
\hline $23 \mathrm{~N}$ & NRCB & $21 \mathrm{Oct}$ & 0710 & 31.50 & 33.50 & 0.37 & 18.5 & Guar & \\
\hline $24 \mathrm{~N}$ & NRCB & $21 \mathrm{Oct}$ & 0745 & 33.50 & 34.50 & 0.73 & 73 & Guar & \\
\hline $25 \mathrm{P}$ & PCA & 21 Oct & 0841 & 34.50 & 35.50 & 0.44 & 44 & Guar & \\
\hline $26 \mathrm{~N}$ & NRCB & 21 Oct & 0910 & 35.50 & 36.50 & 0.95 & 95 & Guar & \\
\hline $27 \mathrm{~N}$ & NRCB & 21 Oct & 0940 & 36.50 & 37.50 & 1.21 & 121 & Guar & \\
\hline $28 \mathrm{~N}$ & NRCB & $21 \mathrm{Oct}$ & 1015 & 37.50 & 38.50 & 0.45 & 45 & Guar & Driller noted a change in drilling parameters within the last $20 \mathrm{~cm}$ \\
\hline $29 \mathrm{~N}$ & NRCB & 21 Oct & 1110 & 38.50 & 39.50 & 0.00 & 0 & Guar & PCD secondary bit lost two buttons and one partially lost \\
\hline $30 \mathrm{~N}$ & NRCB & 21 Oct & 1150 & 39.50 & 40.50 & 0.00 & 0 & Guar & Drilling like sand \\
\hline 315 & $\mathrm{HS}$ & 21 Oct & 1215 & 40.50 & 40.50 & 0.08 & & Guar & \\
\hline \multirow[t]{6}{*}{$32 \mathrm{~N}$} & NRCB & 21 Oct & 1230 & 40.50 & 41.50 & 0.15 & 15 & Guar & Chalk at base of run below more gravel \\
\hline & & 21 Oct & 1255 & & & & & & End of hole \\
\hline & & 21 Oct & 1315 & & & & & & Tripped pipe back to log hole \\
\hline & & & & & & & & & Loggers unable to release brake on winch using ship's air supply; brake freed when ship increased air pressure \\
\hline & & 21 Oct & 1515 & & & & & & Abandoned logging attempt at this hole because ship required to change heading \\
\hline & & 21 Oct & 1520 & & & & & & Dismantled logging tools and exchanged coring tools in readiness for bumping over to Hole M0064B \\
\hline \multicolumn{10}{|c|}{ 347-M0064B- } \\
\hline & & 21 Oct & 1605 & & & & & & Completed bump over from Hole M0064A \\
\hline $1 \mathrm{H}$ & PCS & 21 Oct & 1615 & 0.00 & 3.30 & 3.46 & 104.85 & Seawater & Water $1.22 \mathrm{~m}$ shallower than Hole M0064A \\
\hline $2 \mathrm{H}$ & PCS & 21 Oct & 1655 & 3.30 & 6.60 & 3.26 & 98.79 & Seawater & $\sim 2 \mathrm{~m}$ of sand \\
\hline $3 \mathrm{H}$ & PCS & 21 Oct & 1735 & 6.60 & 7.10 & 0.32 & 64 & Guar & Sand with gravel at base; no possibility of collecting material; open holed to penetrate expected $1.5 \mathrm{~m}$ \\
\hline 40 & NCA & 21 Oct & 1805 & 7.10 & 10.10 & 0.00 & 0 & Guar & Open holed $3 \mathrm{~m}$ from last sample, drilling parameters suggest same or similar material as before \\
\hline $5 S$ & $\mathrm{HS}$ & 21 Oct & 1825 & 10.10 & 10.20 & 0.10 & 100 & Guar & $\begin{array}{l}\text { Sand and gravel; this made } 6 \mathrm{~m} \text { of this material, and with the loss of } 1 \mathrm{~m} \text { when pulling back to take sample, } \\
\text { decision made to end hole }\end{array}$ \\
\hline
\end{tabular}


Table T1 (continued). (Continued on next page.)

\begin{tabular}{|c|c|c|c|c|c|c|c|c|c|}
\hline \multirow[b]{2}{*}{ Core } & \multirow{2}{*}{$\begin{array}{l}\text { Coring } \\
\text { method }\end{array}$} & \multirow{2}{*}{$\begin{array}{l}\text { Date } \\
(2013)\end{array}$} & \multirow{2}{*}{$\begin{array}{l}\text { Time } \\
\text { (UTC) }\end{array}$} & \multicolumn{2}{|c|}{ Depth (mbsf) } & \multirow{2}{*}{$\begin{array}{c}\text { Recovered } \\
(\mathrm{m})\end{array}$} & \multirow{2}{*}{$\begin{array}{l}\text { Recovery } \\
(\%)\end{array}$} & \multirow[b]{2}{*}{ Mud type } & \multirow[b]{2}{*}{ Comments } \\
\hline & & & & Top & Bottom & & & & \\
\hline & & & & & & & & & Pulled pipe clear of seabed and bumped over to Hole M0064C \\
\hline \multicolumn{10}{|c|}{ 347-M0064C- } \\
\hline & & 21 Oct & 1915 & & & & & & Completed bump over from Hole M0064B \\
\hline $1 \mathrm{H}$ & PCS & 21 Oct & 1925 & 0.00 & 3.30 & 3.43 & 103.94 & Seawater & \\
\hline $2 \mathrm{H}$ & PCS & 21 Oct & 2005 & 3.30 & 6.60 & 3.52 & 106.67 & Seawater & Clay; mud valve stuck closed, several attempts to open; no pressure in string \\
\hline $3 \mathrm{H}$ & PCS & 21 Oct & 2050 & 6.60 & 9.90 & 3.33 & 100.91 & Seawater & Slightly sandy clay \\
\hline $4 \mathrm{H}$ & PCS & 21 Oct & 2125 & 9.90 & 12.70 & 2.79 & 99.64 & Seawater & 65 bar but then rose to $>100$ bar; till at bottom of core \\
\hline $5 \mathrm{~N}$ & NRCB & 21 Oct & 2220 & 12.70 & 13.70 & 0.78 & 78 & Seawater & \\
\hline $6 \mathrm{~N}$ & NRCB & 21 Oct & 2305 & 13.70 & 14.70 & 1.07 & 107 & Seawater & \\
\hline $7 \mathrm{~N}$ & NRCB & 21 Oct & 2330 & 14.70 & 15.70 & 0.24 & 24 & Seawater & \\
\hline $8 \mathrm{~N}$ & NRCB & 21 Oct & 2355 & 15.70 & 16.70 & 0.00 & 0 & Seawater & No recovery, liner clean \\
\hline 90 & NCA & 22 Oct & 0020 & 16.70 & 18.70 & 0.00 & 0 & Seawater & \\
\hline $10 \mathrm{~N}$ & NRCB & 22 Oct & 0059 & 18.70 & 19.70 & 0.00 & 0 & Seawater & No recovery, liner clean \\
\hline $11 \mathrm{~N}$ & NRCB & 22 Oct & 0136 & 19.70 & 20.70 & 0.68 & 68 & Seawater & \\
\hline $12 \mathrm{~N}$ & NRCB & 22 Oct & 0214 & 20.70 & 21.70 & 1.34 & 134 & Seawater & May have recovered end of previous run \\
\hline $13 \mathrm{~N}$ & NRCB & 22 Oct & 0250 & 21.70 & 22.70 & 1.32 & 132 & Seawater & \\
\hline $14 \mathrm{~N}$ & NRCB & 22 Oct & 0317 & 22.70 & 23.70 & 1.43 & 143 & Seawater & \\
\hline $15 \mathrm{~N}$ & NRCB & 22 Oct & 0356 & 23.70 & 24.70 & 1.34 & 134 & Seawater & \\
\hline $16 \mathrm{~N}$ & NRCB & 22 Oct & 0443 & 24.70 & 25.70 & 1.20 & 120 & Seawater & \\
\hline $17 \mathrm{~N}$ & NRCB & 22 Oct & 0522 & 25.70 & 26.70 & 1.23 & 123 & Seawater & \\
\hline $18 \mathrm{~N}$ & NRCB & 22 Oct & 0600 & 26.70 & 27.70 & 1.53 & 153 & Seawater & \\
\hline $19 \mathrm{~N}$ & NRCB & 22 Oct & 0627 & 27.70 & 28.70 & 0.70 & 70 & Seawater & \\
\hline $20 \mathrm{~N}$ & NRCB & 22 Oct & 0652 & 28.70 & 29.70 & 1.23 & 123 & Seawater & \\
\hline $21 \mathrm{~N}$ & NRCB & 22 Oct & 0712 & 29.70 & 30.70 & 0.84 & 84 & Seawater & \\
\hline $22 \mathrm{~N}$ & NRCB & 22 Oct & 0753 & 30.70 & 31.70 & 1.23 & 123 & Seawater & \\
\hline $23 \mathrm{~N}$ & NRCB & 22 Oct & 0815 & 31.70 & 32.70 & 1.33 & 133 & Seawater & \\
\hline $24 \mathrm{~N}$ & NRCB & 22 Oct & 0840 & 32.70 & 33.70 & 1.50 & 150 & Seawater & \\
\hline $25 \mathrm{~N}$ & NRCB & 22 Oct & 0905 & 33.70 & 34.70 & 1.26 & 126 & Seawater & \\
\hline $26 \mathrm{~N}$ & NRCB & 22 Oct & 0935 & 34.70 & 35.70 & 1.30 & 130 & Seawater & \\
\hline $27 \mathrm{~N}$ & NRCB & 22 Oct & 1005 & 35.70 & 36.70 & 1.21 & 121 & Seawater & \\
\hline $28 \mathrm{~N}$ & NRCB & 22 Oct & 1035 & 36.70 & 37.70 & 1.48 & 148 & Seawater & \\
\hline $29 \mathrm{~N}$ & NRCB & 22 Oct & 1115 & 37.70 & 38.20 & 0.29 & 58 & Seawater & \\
\hline $30 \mathrm{~s}$ & HS & 22 Oct & 1148 & 38.20 & 38.20 & 0.04 & 0 & Seawater & \\
\hline $31 \mathrm{~N}$ & NRCB & 22 Oct & 1215 & 38.20 & 39.20 & 0.00 & 0 & Seawater & \\
\hline $32 \mathrm{~N}$ & NRCB & 22 Oct & 1310 & 39.20 & 40.20 & 0.00 & 0 & Seawater & \\
\hline $33 \mathrm{~N}$ & NRCB & 22 Oct & 1325 & 40.20 & 42.20 & 0.00 & 0 & Seawater & \\
\hline $34 \mathrm{~N}$ & NRCB & 22 Oct & 1355 & 42.20 & 43.20 & 0.02 & 2 & Seawater & 1 rounded pebble with a smearing of chalk recovered \\
\hline $35 \mathrm{~N}$ & NRCB & 22 Oct & 1355 & 43.20 & 45.00 & 0.00 & 0 & Seawater & \\
\hline \multirow[t]{3}{*}{365} & HS & 22 Oct & 1445 & 45.00 & 45.10 & 0.10 & 100 & Seawater & $\begin{array}{l}\text { Granite and chalk recovered } \\
\text { End of hole }\end{array}$ \\
\hline & & 22 Oct & 1505 & & & & & & Flushed borehole and carried out wiper trips while tripping pipe in preparation for logging \\
\hline & & 22 Oct & 1525 & & & & & & $\begin{array}{l}\text { Hole collapsed from } 9 \text { mbsf; attempted wiper trip unsuccessful; abandoned logging and prepared to bump } \\
\text { over to Hole M0064D }\end{array}$ \\
\hline \multicolumn{10}{|c|}{ 347-M0064D- } \\
\hline & & 22 Oct & 1555 & & & & & & Completed bump over from Hole M0064C \\
\hline $1 \mathrm{H}$ & PCS & 22 Oct & 1625 & 0.00 & 2.20 & 3.02 & 137.27 & Seawater & $43 \mathrm{bar}$; this sea surface sample was the first aromatic core at this location \\
\hline $2 \mathrm{H}$ & PCS & 22 Oct & 1700 & 2.20 & 5.50 & 3.50 & 106.06 & Seawater & $50 \mathrm{bar}$ \\
\hline $3 \mathrm{H}$ & PCS & 22 Oct & 1740 & 5.50 & 8.80 & 3.54 & 107.27 & Seawater & $68 \mathrm{bar}$ \\
\hline $4 \mathrm{H}$ & PCS & 22 Oct & 1819 & 8.80 & 12.10 & 3.47 & 105.15 & Seawater & $100 \mathrm{bar}$, took a second attempt to fall to zero; soft diamicton, attempted another piston \\
\hline $5 \mathrm{H}$ & PCS & 22 Oct & 1859 & 12.10 & 15.40 & 3.69 & 111.82 & Seawater & $\begin{array}{l}\text { Fired at } 62 \mathrm{bar} \text {, dropped to } 50 \mathrm{bar} \text {, rose to } 100 \mathrm{bar} \text {; spline }+2 \text { rings came off overshot release tool; spline was } \\
\text { fished with the magnet and rings recovered; soft diamicton recovered; swap to NRCB for next run }\end{array}$ \\
\hline
\end{tabular}




\begin{tabular}{|c|c|c|c|c|c|c|c|c|c|}
\hline \multirow[b]{2}{*}{ Core } & \multirow{2}{*}{$\begin{array}{l}\text { Coring } \\
\text { method }\end{array}$} & \multirow{2}{*}{$\begin{array}{l}\text { Date } \\
(2013)\end{array}$} & \multirow{2}{*}{$\begin{array}{l}\text { Time } \\
\text { (UTC) }\end{array}$} & \multicolumn{2}{|c|}{ Depth (mbsf) } & \multirow{2}{*}{$\begin{array}{c}\text { - Recovered } \\
\text { (m) }\end{array}$} & \multirow{2}{*}{$\begin{array}{l}\text { Recovery } \\
(\%)\end{array}$} & \multirow[b]{2}{*}{ Mud type } & \multirow[b]{2}{*}{ Comments } \\
\hline & & & & Top & Bottom & & & & \\
\hline $6 \mathrm{~N}$ & $\mathrm{NRCB}$ & 22 Oct & 2025 & 15.40 & 16.40 & 0.00 & 0 & Guar & Possibly did not latch in correctly \\
\hline $7 \mathrm{~N}$ & NRCB & 22 Oct & 2050 & 16.40 & 17.40 & 1.36 & 136 & Guar & Hard diamicton \\
\hline $8 \mathrm{~N}$ & NRCB & 22 Oct & 2130 & 17.40 & 18.20 & 0.71 & 88.75 & Guar & \\
\hline $9 \mathrm{~N}$ & NRCB & 22 Oct & 2213 & 18.20 & 19.20 & 0.00 & 0 & Guar & \\
\hline $10 \mathrm{~N}$ & $\mathrm{NRCB}$ & 22 Oct & 2330 & 19.20 & 20.40 & 0.00 & 0 & Guar & Possibly did not latch in properly \\
\hline $11 \mathrm{~N}$ & NRCB & 23 Oct & 0015 & 20.40 & 21.40 & 0.35 & 35 & Guar & \\
\hline $12 \mathrm{~N}$ & NRCB & 23 Oct & 0045 & 21.40 & 22.40 & 0.20 & 20 & Guar & \\
\hline $13 \mathrm{~N}$ & NRCB & 23 Oct & 0110 & 22.40 & 23.40 & 0.00 & 0 & Guar & \\
\hline 140 & NCA & 23 Oct & 0145 & 23.40 & 25.40 & 0.00 & 0 & Guar & Inserted bit to clear blockage \\
\hline $15 \mathrm{~N}$ & NRCB & 23 Oct & 0218 & 25.40 & 26.40 & 1.15 & 115 & Guar & \\
\hline $16 \mathrm{~N}$ & NRCB & 23 Oct & 0245 & 26.40 & 27.40 & 0.50 & 50 & Guar & \\
\hline 170 & NCA & 23 Oct & 0315 & 27.40 & 28.40 & 0.00 & 0 & Guar & Inserted bit used to clear stone in throat of drill bit \\
\hline $18 \mathrm{~N}$ & $\mathrm{NRCB}$ & 23 Oct & 0329 & 28.40 & 29.40 & 1.44 & 144 & Guar & $\begin{array}{l}\text { Reran NRC for core run; left on a badly worn bit (with a good inside gauge) because stone expected; good } \\
\text { core recovered and bit still usable }\end{array}$ \\
\hline $19 \mathrm{~N}$ & NRCB & 23 Oct & 0356 & 29.40 & 30.40 & 0.66 & 66 & Guar & \\
\hline 200 & NCA & 23 Oct & 0415 & 30.40 & 31.40 & 0.00 & 0 & Guar & Ran insert bit to dig and remove suspected stone in front of bit \\
\hline $21 \mathrm{~N}$ & NRCB & 23 Oct & 0450 & 31.40 & 32.40 & 1.43 & 143 & Guar & Gritty clay core recovered \\
\hline $22 \mathrm{~N}$ & NRCB & 23 Oct & 0522 & 32.40 & 33.40 & 1.3 & 130 & Guar & \\
\hline $23 \mathrm{~N}$ & NRCB & 23 Oct & 0544 & 33.40 & 33.90 & 0.44 & 88 & Guar & Unable to core $1 \mathrm{~m}$, so stopped to retrieve NRCB and set up for NCA to $41 \mathrm{mbsf}$ \\
\hline 240 & NCA & 23 Oct & 0625 & 33.90 & 41.00 & 0.00 & 0 & Guar & Rooster box down at deck level; pulled NCA and prepared to take hammer sample to prove ground \\
\hline \multirow[t]{12}{*}{$25 \mathrm{~S}$} & HS & 23 Oct & 0740 & 41.00 & 41.20 & 0.20 & 100 & Guar & Pea-size gravel recovered \\
\hline & & 23 Oct & 0755 & & & & & & End of hole \\
\hline & & 23 Oct & 0755 & & & & & & Circulated mud; set up logging gear on deck while circulating \\
\hline & & 23 Oct & 0810 & & & & & & Commenced tripping pipe to $10 \mathrm{mbsf}$ \\
\hline & & 23 Oct & 0902 & & & & & & Logging tool reached $31 \mathrm{mbsf}$ \\
\hline & & 23 Oct & 0931 & & & & & & Second string of tools ran in compensation, reached 21 mbsf only; decided not to run third string \\
\hline & & 23 Oct & 1000 & & & & & & Dismantled logging deck and prepared to trip pipe \\
\hline & & 23 Oct & 1015 & & & & & & Tripped pipe \\
\hline & & 23 Oct & 1050 & & & & & & BHA in slips \\
\hline & & 23 Oct & 1050 & & & & & & Lifted template \\
\hline & & 23 Oct & 1105 & & & & & & Cleaned template of cuttings in moonpool \\
\hline & & 23 Oct & 1120 & & & & & & Template on deck \\
\hline
\end{tabular}

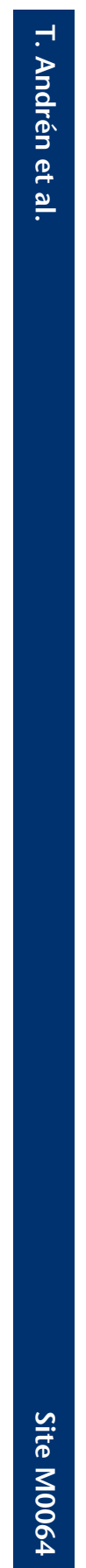

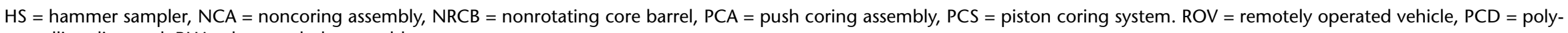
crystalline diamond, $\mathrm{BHA}=$ bottom-hole assembly. 
Table T2. Diatoms, Hole M0064A.

\begin{tabular}{|c|c|c|c|c|}
\hline Affinity & Life form & $\begin{array}{l}\text { Depth (mbsf): } \\
\text { Core, section: }\end{array}$ & $\begin{array}{c}0 \\
1 \mathrm{H}-1\end{array}$ & $\begin{array}{c}6.3 \\
3 \mathrm{H}-1 \\
\text { Barren }\end{array}$ \\
\hline BM & Pelagic & Actinocyclus octonarius Ehrenberg & $\mathrm{x}$ & \\
\hline $\mathrm{BF}$ & Pelagic & Actinocyclus octonarius var. crassus (W. Smith) Hendey & $\mathrm{x}$ & \\
\hline BM & Pelagic & Chaetoceros resting spores spp. & $\mathrm{x}$ & \\
\hline BM & Pelagic & Chaetoceros spp. vegetative cells & $\mathrm{x}$ & \\
\hline B & Epiphytic & Cocconeis scutellum Ehrenberg & $\mathrm{x}$ & \\
\hline B & Pelagic & Coscinodiscus granii Gough & $\mathrm{x}$ & \\
\hline B & Pelagic and epilithic & Cyclotella choctawhatcheeana Prasad & $\mathrm{x}$ & \\
\hline $\mathrm{BF}$ & Epiphytic & Epithemia turgida (Ehrenberg) Kützing & $\mathrm{x}$ & \\
\hline BM & Epiphytic & Grammatophora oceanica Ehrenberg & $\mathrm{x}$ & \\
\hline M & Epiphytic & Hyalodiscus scoticus (Kützing) Grunow & $\mathrm{x}$ & \\
\hline B & Pelagic and on ice & Melosira arctica Dickie & $\mathrm{x}$ & \\
\hline B & Pelagic and ice & Pauliella taeniata (Grunow) Round and Basson & $\mathrm{x}$ & \\
\hline M & Pelagic & Pseudosolenia calcar-avis (Schultze) B.G. Sundström & $\mathrm{x}$ & \\
\hline B & Epiphytic and epilithic & Rhoicosphenia curvata (Kützing) Grunow & $\mathrm{x}$ & \\
\hline B & Pelagic & Thalassiosira hyperborea var. lacunosa (Berg) Hasle & $\mathrm{x}$ & \\
\hline \multirow[t]{5}{*}{ B } & Pelagic & Thalassiosira levanderi Van Goor & $\mathrm{x}$ & \\
\hline & & Crysophyte cysts & & \\
\hline & & Smooth & $\mathrm{x}$ & \\
\hline & & With curves & $\mathrm{x}$ & \\
\hline & & Dots & & \\
\hline
\end{tabular}

$\mathrm{BF}=$ brackish-freshwater, $\mathrm{B}=$ brackish, $\mathrm{BM}=$ brackish-marine, $\mathrm{M}=$ marine $\mathrm{x}=$ present. 
Table T3. Interstitial water geochemistry, Site M0064

\begin{tabular}{|c|c|c|c|c|c|c|c|c|c|c|c|c|c|c|c|c|c|c|c|c|c|c|c|c|c|}
\hline Core, section, interval (cm) & Type & $\begin{array}{c}\text { Depth } \\
\text { (mbst) }\end{array}$ & $\begin{array}{c}\text { Volume } \\
(\mathrm{mL})\end{array}$ & $\begin{array}{l}\text { Analyte: } \\
\text { Unit: } \\
\text { Method: }\end{array}$ & $\begin{array}{l}\text { pH } \\
\text { ISE }\end{array}$ & $\begin{array}{c}\text { Salinity } \\
\text { Refraction }\end{array}$ & $\begin{array}{l}\text { Alkalinity } \\
\text { meq/L } \\
\text { Titration }\end{array}$ & $\begin{array}{l}\mathrm{Cl} \\
\mathrm{mM} \\
\mathrm{IC}\end{array}$ & $\begin{array}{l}\mathrm{Br} \\
\mathrm{mM} \\
\mathrm{IC}\end{array}$ & $\begin{array}{l}\mathrm{SO}_{4}^{2-} \\
\mathrm{mM} \\
\mathrm{IC}\end{array}$ & $\begin{array}{c}\mathrm{H}_{2} \mathrm{~S} \\
\mathrm{mM} \\
\text { Photometrical }\end{array}$ & $\begin{array}{c}\mathrm{NH}_{4}^{+} \\
\mathrm{mM} \\
\text { Conductivity }\end{array}$ & $\begin{array}{c}\mathrm{Na}^{+} \\
\mathrm{mM} \\
\text { ICP-OES }\end{array}$ & $\begin{array}{c}\mathrm{K}^{+} \\
\mathrm{mM} \\
\text { ICP-OES }\end{array}$ & $\begin{array}{c}\mathrm{Mg}^{2+} \\
\mathrm{mM} \\
\text { ICP-OES }\end{array}$ & $\begin{array}{c}\mathrm{Ca}^{2+} \\
\mathrm{mM} \\
\text { ICP-OES }\end{array}$ & 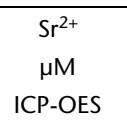 & $\begin{array}{c}\mathrm{Lit}^{\mathrm{L}^{+}} \\
\text {MM } \\
\text { ICP-OES }\end{array}$ & $\begin{array}{c}\mathrm{H}_{4} \mathrm{SiO}_{4} \\
\text { HM } \\
\text { ICP-OES }\end{array}$ & $\begin{array}{c}\mathrm{Ba}^{2+} \\
\mathrm{HM} \\
\text { ICP-OES }\end{array}$ & $\begin{array}{c}\text { B } \\
\text { IM } \\
\text { ICP-OES }\end{array}$ & $\begin{array}{c}\text { Al } \\
\text { HM } \\
\text { ICP-OES }\end{array}$ & $\begin{array}{l}\mathrm{PO}_{4}{ }^{3-} \\
\mathrm{mM} \\
\text { ICP-OES }\end{array}$ & $\begin{array}{c}\mathrm{Fe}^{2+} \\
\mu \mathrm{M} \\
\mathrm{ICP}-\mathrm{OES}\end{array}$ & $\begin{array}{c}\mathrm{Mn}^{2+} \\
\mu \mathrm{M} \\
\text { ICP-OES }\end{array}$ \\
\hline 347-M0064A- & & & & & & & & & & & & & & & & & & & & & & & & & \\
\hline $\begin{array}{l}1 \mathrm{H}-1,135-140 \\
1 \text { H-2, } 105-100\end{array}$ & $\begin{array}{l}\mathrm{Rh} \\
\mathrm{Rh}\end{array}$ & $\begin{array}{l}1.38 \\
2.58\end{array}$ & $\begin{array}{l}16.00 \\
11.00\end{array}$ & & $\begin{array}{l}7.78 \\
7.52\end{array}$ & $\begin{array}{l}13.80 \\
13.90\end{array}$ & $\begin{array}{l}5.46 \\
4.82\end{array}$ & $\begin{array}{l}215.14 \\
210.05\end{array}$ & $\begin{array}{l}0.33 \\
0.34\end{array}$ & $\begin{array}{l}8.80 \\
900\end{array}$ & - & 0.31 & $\begin{array}{l}240.84 \\
21214\end{array}$ & $\begin{array}{l}4.68 \\
3.49\end{array}$ & $\begin{array}{r}23.55 \\
21.09\end{array}$ & 11.68 & $\begin{array}{c}55.09 \\
57.74\end{array}$ & $\begin{array}{r}9.49 \\
1019\end{array}$ & $\begin{array}{l}241.27 \\
24654\end{array}$ & 0.21 & 189.62 & 0.93 & 0.03 & ${ }_{14.64}^{64.64}$ & 38.88 \\
\hline $\begin{array}{l}H-2,105-110 \\
2 H-1,135-140\end{array}$ & $\begin{array}{l}\mathrm{Rh} \\
\mathrm{Rh}\end{array}$ & $\begin{array}{l}2.38 \\
4.38\end{array}$ & $\begin{array}{l}11.00 \\
13.50\end{array}$ & & $\begin{array}{l}7.52 \\
7.41\end{array}$ & $\begin{array}{l}13.90 \\
14.50\end{array}$ & $\begin{array}{l}4.82 \\
4.37\end{array}$ & $\begin{array}{l}219.903 \\
226.84\end{array}$ & $\begin{array}{l}0.34 \\
0.35\end{array}$ & $\begin{array}{l}9.00 \\
8.99\end{array}$ & $=$ & $\begin{array}{l}0.31 \\
0.29\end{array}$ & $\begin{array}{l}212.14 \\
203.65\end{array}$ & $\begin{array}{l}3.49 \\
2.52\end{array}$ & $\begin{array}{l}21.09 \\
18.89\end{array}$ & $\begin{array}{l}13.43 \\
16.37\end{array}$ & $\begin{array}{l}51.74 \\
65.85\end{array}$ & $\begin{array}{l}10.19 \\
12.42\end{array}$ & $\begin{array}{l}246.34 \\
271.32\end{array}$ & $\begin{array}{l}0.20 \\
0.23\end{array}$ & $\begin{array}{r}14 / .44 \\
94.72\end{array}$ & $\begin{array}{l}2.22 \\
3.19\end{array}$ & $\begin{array}{l}0.01 \\
0.01\end{array}$ & $\begin{array}{l}171.71 \\
184.62\end{array}$ & $\begin{array}{l}44.03 \\
54.36\end{array}$ \\
\hline & ${ }_{\mathrm{Rh}}^{\mathrm{Kn}}$ & 5.58 & and & & 7.41 & & 4.00 & & 0.35 & 8.62 & - & 0.31 & 185.78 & 20 & & 17.90 & 71. & 13.72 & 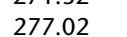 & 0.27 & 64. & & 001 & & 56.85 \\
\hline $3 \mathrm{H}-1,1$ & $\mathrm{Rh}$ & 7.68 & 10.00 & & 7.32 & 14.20 & 3.73 & 222.94 & 0.34 & 6.28 & - & 0.35 & 196.82 & $1.2 \mathrm{C}-\mathrm{s}$ & 18.75 & 21.83 & 94.92 & 15.21 & 268.11 & 0.25 & 55.87 & 3 & 01 & 203.60 & 54.82 \\
\hline $3 \mathrm{H}-2,11$ & $\mathrm{Rh}$ & 8.98 & 13.00 & & 7.45 & 13.50 & 3.58 & 217.73 & 0.34 & 5.75 & - & 0.39 & 202.13 & 1.55 & 21.29 & 24.66 & 125.20 & 17.27 & 321.70 & 0.20 & 69.37 & 0.30 & 0.01 & 173.09 & 35.76 \\
\hline $4 \mathrm{H}-1,135-140$ & $\mathrm{Rh}$ & 10.98 & 11.00 & & 7.49 & 11.00 & 2.95 & 178.39 & 0.28 & 4.88 & - & 0.38 & 157.59 & 1.56 & 15.92 & 15.71 & 85.64 & 12.77 & 243.48 & 0.17 & 67.80 & 3.56 & 0.01 & 150.79 & 25.08 \\
\hline $4 \mathrm{H}-2,104-109$ & Rh & 12.17 & 10.50 & & 7.41 & 11.70 & 3.21 & 188.56 & 0.29 & 5.46 & - & 0.35 & 170.33 & 1.46 & 16.38 & 17.44 & 87.32 & 13.79 & 275.45 & 0.17 & 62.25 & 0.74 & 0.01 & 175.92 & 32.94 \\
\hline 347-M0064B- & & & & & & & & & & & & & & & & & & & & & & & & & \\
\hline $1 \mathrm{H}-1,135-140$ & $\mathrm{Rh}$ & 1.38 & 11.50 & & & 13.35 & 3.46 & 206.34 & 0.32 & 10.08 & - & 0.07 & 179.03 & 3.72 & 18.86 & 9.76 & 48.36 & 11.14 & 225.35 & 0.12 & 148.46 & 3.15 & 0.01 & 73.54 & 40.50 \\
\hline $\begin{array}{l}1 \mathrm{H}-2,105-110 \\
2 \mathrm{H}-1\end{array}$ & $\mathrm{Rh}$ & 2.58 & $\begin{array}{r}8.50 \\
2000\end{array}$ & & 7.67 & 13.61 & 3.52 & 211.61 & 0.32 & 9.75 & - & 0.16 & 183.82 & 3.16 & 18.44 & 12.76 & 60.25 & 12.27 & 222.11 & 0.15 & 118.03 & 0.33 & 0.01 & 110.72 & 45.54 \\
\hline $\begin{array}{l}2 \mathrm{H}-1,95,-100 \\
2 \mathrm{H}-2,114-119\end{array}$ & $\begin{array}{l}\mathrm{Rh} \\
\mathrm{Rh}\end{array}$ & 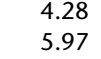 & $\begin{array}{l}32.00 \\
20.00\end{array}$ & & $\begin{array}{l}7.45 \\
7.78 \\
\end{array}$ & $\begin{array}{l}14.28 \\
14.07\end{array}$ & $\begin{array}{l}3.58 \\
3.55\end{array}$ & $\begin{array}{l}221.76 \\
220.19\end{array}$ & $\begin{array}{l}0.34 \\
0.34\end{array}$ & $\begin{array}{l}8.92 \\
6.40\end{array}$ & - & $\begin{array}{l}0.25 \\
0.28\end{array}$ & $\begin{array}{l}176.12 \\
202.00\end{array}$ & $\begin{array}{l}2.24 \\
2.29\end{array}$ & $\begin{array}{l}17.88 \\
19.82\end{array}$ & $\begin{array}{l}16.32 \\
21.26\end{array}$ & $\begin{array}{r}77.66 \\
103.72\end{array}$ & $\begin{array}{l}14.03 \\
15.21\end{array}$ & $\begin{array}{l}272.28 \\
261.56\end{array}$ & $\begin{array}{l}0.10 \\
0.20\end{array}$ & $\begin{array}{l}79.83 \\
61.05\end{array}$ & $\begin{array}{l}0.44 \\
3.11\end{array}$ & $\begin{array}{l}0.01 \\
0.01\end{array}$ & $\begin{array}{l}181.04 \\
46.86\end{array}$ & $\begin{array}{l}39.07 \\
24.52\end{array}$ \\
\hline 347-M0064C- & & & & & & & & & & & & & & & & & & & & & & & & & \\
\hline $1 \mathrm{H}-1,1$ & Rh & 1.38 & 15.00 & & 7.77 & 13.90 & 3.76 & 210.02 & 0.32 & 10.53 & - & 0.13 & 185.56 & 3.92 & 19.31 & 7.99 & 40.42 & 10.37 & 197.01 & 0.07 & 167.88 & 1.59 & 0.02 & 65.63 & 37.68 \\
\hline $1 \mathrm{H}-2,114-119$ & Rh & 2.67 & 10.00 & & 7.68 & 14.70 & 3.71 & 220.92 & 0.34 & 10.94 & - & 0.16 & 198.52 & 3.41 & 19.95 & 12.16 & 54.11 & 11.34 & 238.67 & 0.12 & 138.10 & 0.33 & 0.01 & 121.48 & 51.14 \\
\hline $2 \mathrm{H}-1,1$ & $\mathrm{Rh}$ & 4.68 & 8.00 & & 7.64 & 15.00 & 3.611 & 224.52 & 0.35 & 10.56 & - & 0.20 & 223.49 & 2.62 & 22.28 & 19.45 & 81.77 & 13.18 & 312.55 & 0.22 & 97.49 & 3.41 & 0.01 & 186.77 & 68.18 \\
\hline $2 \mathrm{H}-2,115-120$ & Rh & 5.98 & 12.00 & & 7.55 & 15.40 & 3.74 & 232.43 & 0.36 & 10.41 & - & 0.24 & 242.63 & 2.21 & 24.19 & 23.56 & 103.86 & 15.03 & 303.93 & 0.22 & 85.47 & 0.44 & 0.01 & 222.22 & 70.37 \\
\hline $\begin{array}{l}3 \mathrm{H}-1,135-140 \\
3 \mathrm{H}-2,115-120\end{array}$ & $\begin{array}{l}\text { Rh } \\
\text { ph }\end{array}$ & $\begin{array}{l}7.988 \\
7.988\end{array}$ & 16.00 & & $7,6.62$ & $\begin{array}{l}15.30 \\
1380\end{array}$ & $\begin{array}{l}3.64 \\
3.65\end{array}$ & $\begin{array}{l}230.70 \\
20.70\end{array}$ & 0.35 & $\begin{array}{l}9.93 \\
.97\end{array}$ & - & 0.28 & 193.87 & 1.52 & 20.10 & 19.87 & 97.48 & 16.99 & 266.80 & 0. & 55.41 & & & 122.75 & 19.35 \\
\hline $3 H-2,115-1<0$ & $\begin{array}{l}\text { kn } \\
\text { ph }\end{array}$ & 9.28 & $\begin{array}{l}3.00 \\
100\end{array}$ & & 1.09 & $\begin{array}{l}13.80 \\
1180\end{array}$ & 2.83 & 211.29 & 0.33 & 8.97 & $\bar{z}$ & 0.28 & 199.13 & 1.49 & 20.60 & 20.66 & 103.32 & 10.69 & 324.19 & 0.17 & 61.33 & 0.48 & 0.01 & 119.22 & 25.74 \\
\hline $4 \mathrm{H}-2,92-97$ & $\mathrm{Rh}$ & 12.35 & 3.00 & & 7.73 & 12.90 & 2.31 & 199.74 & 0.31 & 5.99 & - & 0.37 & 158.63 & 1.02 & 17.55 & 18.35 & 100.75 & 16.32 & 242.34 & 0.09 & 58.37 & 7.23 & $\overline{0.01}$ & 100.60 & 10.04 \\
\hline 347-M0064D & & & & & & & & & & & & & & & & & & & & & & & & & \\
\hline & $\mathrm{Rh}$ & 1.35 & 21.00 & & 7.87 & & 5.55 & 204.72 & 0.32 & $\begin{array}{l}8.95 \\
0.77\end{array}$ & - & 0.26 & & 4.38 & 19.85 & 6.36 & 37.40 & 9.91 & 419.80 & 0.09 & 181.30 & 0.26 & 0.05 & 0.00 & 30.48 \\
\hline & $\begin{array}{l}\mathrm{Rh} \\
\mathrm{Rh}\end{array}$ & $\begin{array}{l}2.47 \\
3.55\end{array}$ & $\begin{array}{l}13.00 \\
12.00\end{array}$ & & 7.84 & $\begin{array}{l}13.90 \\
14.60\end{array}$ & $\begin{array}{l}4.67 \\
4.20\end{array}$ & $\begin{array}{l}212.48 \\
221.76\end{array}$ & $\begin{array}{l}0.33 \\
0.34\end{array}$ & 9.71 & - & $0.33-2$ & $\begin{array}{l}185.69 \\
1947\end{array}$ & $\begin{array}{l}3.89 \\
3.19\end{array}$ & $\begin{array}{l}19.20 \\
1849\end{array}$ & 1233 & $\begin{array}{l}41.29 \\
52.72\end{array}$ & 1108 & $\begin{array}{l}187.04 \\
2256\end{array}$ & 0.12 & $\begin{array}{l}157.99 \\
13181\end{array}$ & $\begin{array}{l}0.52 \\
0.48\end{array}$ & 0.02 & $\begin{array}{r}32.45 \\
11585\end{array}$ & $\begin{array}{l}42.09 \\
51.67\end{array}$ \\
\hline & $\begin{array}{l}\mathrm{Kn} \\
\mathrm{Rh}\end{array}$ & 4.85 & $\begin{array}{l}22.00 \\
10.00\end{array}$ & & 7.56 & $\begin{array}{l}14.60 \\
14.80\end{array}$ & $\begin{array}{l}4.20 \\
3.97\end{array}$ & $\begin{array}{l}225.84 \\
225\end{array}$ & $\begin{array}{l}0.34 \\
0.35\end{array}$ & $\begin{array}{l}10.06 \\
9.89\end{array}$ & - & 0.24 & $\begin{array}{l}192.44 \\
182.04\end{array}$ & 19 & $\begin{array}{l}18.49 \\
18.07\end{array}$ & $\begin{array}{l}12.33 \\
15.09\end{array}$ & $\begin{array}{l}52.12 \\
61.06\end{array}$ & $\begin{array}{l}11.08 \\
12.39\end{array}$ & $\begin{array}{l}243.000 \\
246.82\end{array}$ & 0.17 & $\begin{array}{l}151.81 \\
93.05\end{array}$ & $\begin{array}{l}0.48 \\
0.44\end{array}$ & 0.01 & $\begin{array}{l}1535.85 \\
156.49\end{array}$ & $\begin{array}{l}31.07 \\
56.85\end{array}$ \\
\hline $3 \mathrm{H}$ & $\mathrm{Rh}$ & 6.85 & 9.5 & & 7.46 & 14.90 & 3.75 & 227.98 & 0.35 & 9.19 & - & $\begin{array}{l}0.24 \\
0.27\end{array}$ & $\begin{array}{l}18.24 \\
187.52\end{array}$ & $\begin{array}{l}2.39 \\
1.62\end{array}$ & 18.70 & 20.22 & 81.64 & 14.16 & $\begin{array}{l}240.12 \\
290.12\end{array}$ & 0.23 & $\begin{array}{l}64.56 \\
64.56\end{array}$ & $\begin{array}{l}0.44 \\
0.44\end{array}$ & 0.01 & $\begin{array}{l}106.49 \\
196.08\end{array}$ & $\begin{array}{l}50.83 \\
66.42\end{array}$ \\
\hline $3 \mathrm{H}$ & $\mathrm{Rh}$ & 8.16 & 10.00 & & 7.43 & 15.10 & 3.66 & 232.37 & 0.36 & 8.73 & - & 30 & 225.79 & 1.60 & 21.80 & 25.48 & 108.89 & 15.11 & 312.59 & 0.29 & 63.92 & 0.89 & 01 & 232.61 & 69.39 \\
\hline $4 \mathrm{H}-1,1$ & $\mathrm{Rh}$ & 10.15 & 6.5 & & 7.53 & 12.20 & 3.06 & 215.04 & 0.33 & 5.72 & - & 0.35 & 191.26 & 1.30 & 20.18 & 24.86 & 122.57 & 15.63 & 321.06 & 0.17 & 66.23 & 1.30 & 0.01 & 171.37 & 27.35 \\
\hline & $\mathrm{Rh}$ & 11.45 & 2.30 & & 7.93 & 13.80 & 2.70 & 191.48 & 0.30 & 4.29 & - & 0.40 & 144.32 & 1.12 & 15.73 & 19.41 & 108.45 & 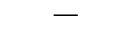 & 182.16 & 0.21 & 52.54 & 0.44 & 0.01 & 4.71 & 11.71 \\
\hline $\begin{array}{l}5 \mathrm{H}-1,1,130-135 \\
5-2,110-115\end{array}$ & $\begin{array}{l}\mathrm{Rh} \\
\mathrm{Rh}\end{array}$ & $\begin{array}{l}13.45 \\
14.75\end{array}$ & $\begin{array}{l}0.00 \\
6.50\end{array}$ & & 7.45 & 12.70 & 2.94 & 199.59 & 0.31 & 4.51 & - & 0.41 & 174.77 & 1.27 & 19.49 & 23.96 & 137.75 & 15.83 & 391.67 & 0.32 & 74.55 & 1.63 & 0.01 & 231.89 & 12.99 \\
\hline Reference & & & & & & & & & & & & & & & & & & & & & & & & & \\
\hline & $=$ & - & - & & $\begin{array}{l}7.45 \\
7.69\end{array}$ & $\begin{array}{ll}170.6 \\
116 .\end{array}$ & $\begin{array}{l}2.35 \\
2.14\end{array}$ & $\begin{array}{r}3448.94 \\
2659\end{array}$ & 0. & $\begin{array}{l}17.47 \\
116.8\end{array}$ & 0. & 0.00 & $\begin{array}{l}3372.77 \\
25427\end{array}$ & 5.85 & 14 & 12.4 & 420. & 6.4 & 35.78 & 8.98 & $\begin{array}{l}137.36 \\
187777\end{array}$ & 0.22 & 0.01 & 13.54 & 先6 \\
\hline $\begin{array}{l}\mathrm{R} 3 \\
\mathrm{R} 4\end{array}$ & - & - & $\overline{-}$ & & & $\begin{array}{r}1.8 \\
2.5\end{array}$ & $\begin{array}{l}2.14 \\
0.26\end{array}$ & $\begin{array}{r}26.91 \\
0.18\end{array}$ & $\begin{array}{l}.33 \\
0.00\end{array}$ & $\begin{array}{l}0.08 \\
0.01\end{array}$ & 0. & 0. & $\begin{array}{r}25.37 \\
0.00\end{array}$ & 0. & $\begin{array}{r}23 . \\
0 .\end{array}$ & $\begin{array}{l}3 . \\
0 .\end{array}$ & $\begin{array}{r}43 . \\
0 .\end{array}$ & 1. & 0. & $\begin{array}{l}3.18 \\
4.69\end{array}$ & $\begin{array}{r}818.17 \\
8.69\end{array}$ & & & 0.00 & $\begin{array}{l}2.88 \\
2.86\end{array}$ \\
\hline${ }^{N 4}$ & - & - & - & & & $=0$ & 0.27 & 0.10 & 0.00 & 0.00 & 0. & & 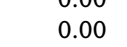 & 0. & 0. & & & 1. & & $\begin{array}{l}4.09 \\
4.05\end{array}$ & $\begin{array}{l}8.099 \\
6.94\end{array}$ & & & 0.00 & $\begin{array}{l}2.00 \\
2.86\end{array}$ \\
\hline & - & - & - & & & & 0. & 3 & 0. & & & & 50 & 0 & 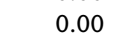 & & & & & 30 & & & & & 86 \\
\hline ton rod grease & - & - & - & & 4. & 0.00 & 0. & 5 & 0. & & & 0.8 & 00 & 0. & 0. & & 0. & 0 & 0.00 & 0.43 & 99 & & 0.01 & 0 & 2.86 \\
\hline e thread & - & - & - & & 6. & 5.56 & 0. & 0.39 & 0. & 0.03 & 0. & 0. & 0.00 & 0.00 & 0. & 0.00 & 0 & 1. & 0.61 & 3. & 84 & 0.00 & 0.01 & 0 & 86 \\
\hline & - & - & - & & 6. & 0 & 0. & 6 & 0. & 4 & 0.0 & 0.00 & 55 & 0. & 0. & 0 & $\begin{array}{l}0 \\
0 \\
0\end{array}$ & 0. & $\begin{array}{l}7.23 \\
0.53\end{array}$ & 8.71 & $\begin{array}{r}104.80 \\
0.00\end{array}$ & 0.22 & 01 & 00 & 89 \\
\hline S550) & - & $=$ & - & & 7. & $\begin{array}{l}0.00 \\
41.48\end{array}$ & . & & & $\begin{array}{r}0.00 \\
20.60\end{array}$ & $\begin{array}{l}0 . \\
0 .\end{array}$ & 1. & & $\begin{array}{l}0 . \\
9 .\end{array}$ & $\begin{array}{r}0 \\
41\end{array}$ & 8.83 & $\begin{array}{c}0 . \\
98 .\end{array}$ & $\begin{array}{r}0 \\
19\end{array}$ & 23.1 & $\begin{array}{l}1.30 \\
1.69\end{array}$ & & & & 90 & 86 \\
\hline & - & - & - & & 6. & 16 & 2. & & & 12.35 & 0. & 0.0 & & 5. & 24 & $\begin{array}{l}0.03 \\
4.91\end{array}$ & $\begin{array}{l}30 . \\
36 .\end{array}$ & & 8. & $\begin{array}{l}1.09 \\
1.94\end{array}$ & & & & .00 & .02 \\
\hline $\begin{array}{l}\text { ater/drill wa } \\
\text { ater }\end{array}$ & - & - & - & & 7. & 14.94 & 2.4 & & & 8.87 & 0.0 & 0.00 & 216.62 & 5.0 & 24 & 4.5 & 37 & 12. & 5.70 & 1.88 & 190.2 & & & 56 & $\begin{array}{l}3.92 \\
2.93\end{array}$ \\
\hline R26 M0064/surface seavater & - & - & - & & 7.76 & 6.54 & 1.85 & 113.81 & 0.17 & 5.96 & 0.00 & 0.00 & 103.57 & 2.36 & 11.62 & 2.79 & 18.63 & 5.17 & 6.94 & 0.02 & 88.34 & 0.15 & 0.01 & 0.00 & 2.87 \\
\hline
\end{tabular}

Rh = Rhizon sample. ISE = ion-specific electrode, IC = ion chromatography, ICP-OES = inductively coupled plasma-optical emission spectroscopy. $-=$ no data reported for samples with insufficient pore water volumes. 
Table T4. Calculated salinity and elemental ratios of interstitial waters, Site M0064.

\begin{tabular}{|c|c|c|c|c|c|c|c|c|c|c|}
\hline $\begin{array}{l}\text { Core, section, } \\
\text { interval }(\mathrm{cm})\end{array}$ & Type & $\begin{array}{l}\text { Depth } \\
\text { (mbsf) }\end{array}$ & $\begin{array}{l}\mathrm{Cl}^{-} \text {based } \\
\text { salinity }\end{array}$ & $\begin{array}{c}\mathrm{Na} / \mathrm{Cl} \\
(\mathrm{mM} / \mathrm{mM})\end{array}$ & $\begin{array}{c}\mathrm{Ca} / \mathrm{Cl} \\
(\mathrm{mM} / \mathrm{mM})\end{array}$ & $\begin{array}{c}\mathrm{Mg} / \mathrm{Cl} \\
(\mathrm{mM} / \mathrm{mM})\end{array}$ & $\begin{array}{c}\mathrm{K} / \mathrm{Cl} \\
(\mathrm{mM} / \mathrm{mM})\end{array}$ & $\begin{array}{c}\mathrm{Br} / \mathrm{Cl} \\
(\mu \mathrm{M} / \mathrm{mM})\end{array}$ & $\begin{array}{c}\mathrm{B} / \mathrm{Cl} \\
(\mu \mathrm{M} / \mathrm{mM})\end{array}$ & $\begin{array}{c}\mathrm{SO}_{4} / \mathrm{Cl} \\
(\mathrm{mM} / \mathrm{mM})\end{array}$ \\
\hline \multicolumn{11}{|l|}{ 347-M0064A- } \\
\hline $1 \mathrm{H}-1,135-140$ & $\mathrm{Rh}$ & 1.38 & 13.5 & 1.12 & 0.05 & 0.11 & 0.02 & 1.54 & 0.88 & 0.041 \\
\hline $1 \mathrm{H}-2,105-110$ & $\mathrm{Rh}$ & 2.58 & 13.7 & 0.97 & 0.06 & 0.10 & 0.02 & 1.53 & 0.67 & 0.041 \\
\hline $2 \mathrm{H}-1,135-140$ & $\mathrm{Rh}$ & 4.38 & 14.2 & 0.90 & 0.07 & 0.08 & 0.01 & 1.54 & 0.42 & 0.040 \\
\hline $2 \mathrm{H}-2,105-110$ & $\mathrm{Rh}$ & 5.58 & 14.2 & 0.82 & 0.08 & 0.08 & 0.01 & 1.54 & 0.28 & 0.038 \\
\hline $3 \mathrm{H}-1,135-140$ & $\mathrm{Rh}$ & 7.68 & 14.0 & 0.88 & 0.10 & 0.08 & 0.01 & 1.54 & 0.25 & 0.028 \\
\hline $3 \mathrm{H}-2,115-120$ & $\mathrm{Rh}$ & 8.98 & 13.7 & 0.93 & 0.11 & 0.10 & 0.01 & 1.55 & 0.32 & 0.026 \\
\hline $4 \mathrm{H}-1,135-140$ & $\mathrm{Rh}$ & 10.98 & 11.2 & 0.88 & 0.09 & 0.09 & 0.01 & 1.57 & 0.38 & 0.027 \\
\hline $4 \mathrm{H}-2,104-109$ & $\mathrm{Rh}$ & 12.17 & 11.8 & 0.90 & 0.09 & 0.09 & 0.01 & 1.55 & 0.33 & 0.029 \\
\hline \multicolumn{11}{|l|}{ 347-M0064B- } \\
\hline $1 \mathrm{H}-1,135-140$ & $\mathrm{Rh}$ & 1.38 & 12.9 & 0.87 & 0.05 & 0.09 & 0.02 & 1.53 & 0.72 & 0.049 \\
\hline $1 \mathrm{H}-2,105-110$ & $\mathrm{Rh}$ & 2.58 & 13.3 & 0.87 & 0.06 & 0.09 & 0.01 & 1.53 & 0.56 & 0.046 \\
\hline $2 \mathrm{H}-1,95-100$ & $\mathrm{Rh}$ & 4.28 & 13.9 & 0.79 & 0.07 & 0.08 & 0.01 & 1.54 & 0.36 & 0.040 \\
\hline $2 \mathrm{H}-2,114-119$ & $\mathrm{Rh}$ & 5.97 & 13.8 & 0.92 & 0.10 & 0.09 & 0.01 & 1.55 & 0.28 & 0.029 \\
\hline \multicolumn{11}{|l|}{ 347-M0064C- } \\
\hline $1 \mathrm{H}-1,135-140$ & $\mathrm{Rh}$ & 1.38 & 13.2 & 0.88 & 0.04 & 0.09 & 0.02 & 1.53 & 0.80 & 0.050 \\
\hline $1 \mathrm{H}-2,114-119$ & $\mathrm{Rh}$ & 2.67 & 13.9 & 0.90 & 0.06 & 0.09 & 0.02 & 1.53 & 0.63 & 0.050 \\
\hline $2 \mathrm{H}-1,135-140$ & $\mathrm{Rh}$ & 4.68 & 14.1 & 1.00 & 0.09 & 0.10 & 0.01 & 1.54 & 0.43 & 0.047 \\
\hline $2 \mathrm{H}-2,115-120$ & $\mathrm{Rh}$ & 5.98 & 14.6 & 1.04 & 0.10 & 0.10 & 0.01 & 1.54 & 0.37 & 0.045 \\
\hline $3 \mathrm{H}-1,135-140$ & $\mathrm{Rh}$ & 7.98 & 14.5 & 0.84 & 0.09 & 0.09 & 0.01 & 1.54 & 0.24 & 0.043 \\
\hline $3 \mathrm{H}-2,115-120$ & $\mathrm{Rh}$ & 9.28 & 13.3 & 0.94 & 0.10 & 0.10 & 0.01 & 1.54 & 0.29 & 0.042 \\
\hline $4 \mathrm{H}-1,135-140$ & $\mathrm{Rh}$ & 11.28 & - & - & - & - & - & - & - & - \\
\hline $4 \mathrm{H}-2,92-97$ & $\mathrm{Rh}$ & 12.35 & 12.5 & 0.79 & 0.09 & 0.09 & 0.01 & 1.56 & 0.29 & 0.030 \\
\hline \multicolumn{11}{|l|}{ 347-M0064D- } \\
\hline $1 \mathrm{H}-1,130-135$ & $\mathrm{Rh}$ & 1.35 & 12.8 & 0.92 & 0.10 & 0.10 & 0.02 & 1.55 & 0.89 & 0.044 \\
\hline $1 \mathrm{H}-2,92-97$ & $\mathrm{Rh}$ & 2.47 & 13.3 & 0.87 & 0.09 & 0.09 & 0.02 & 1.54 & 0.74 & 0.046 \\
\hline $2 \mathrm{H}-1,130-135$ & $\mathrm{Rh}$ & 3.55 & 13.9 & 0.87 & 0.08 & 0.08 & 0.01 & 1.55 & 0.59 & 0.045 \\
\hline $2 \mathrm{H}-2,110-115$ & $\mathrm{Rh}$ & 4.85 & 14.2 & 0.81 & 0.08 & 0.08 & 0.01 & 1.54 & 0.41 & 0.044 \\
\hline $3 \mathrm{H}-1,130-135$ & $\mathrm{Rh}$ & 6.85 & 14.3 & 0.82 & 0.08 & 0.08 & 0.01 & 1.55 & 0.28 & 0.040 \\
\hline $3 \mathrm{H}-2,111-116$ & $\mathrm{Rh}$ & 8.16 & 14.6 & 0.97 & 0.09 & 0.09 & 0.01 & 1.55 & 0.28 & 0.038 \\
\hline $4 \mathrm{H}-1,130-135$ & $\mathrm{Rh}$ & 10.15 & 13.5 & 0.89 & 0.09 & 0.09 & 0.01 & 1.55 & 0.31 & 0.027 \\
\hline $4 \mathrm{H}-2,110-115$ & $\mathrm{Rh}$ & 11.45 & 12.0 & 0.75 & 0.08 & 0.08 & 0.01 & 1.57 & 0.27 & 0.022 \\
\hline $5 \mathrm{H}-1,130-135$ & $\mathrm{Rh}$ & 13.45 & - & - & - & - & - & - & - & - \\
\hline $5 \mathrm{H}-2,110-115$ & $\mathrm{Rh}$ & 14.75 & 12.5 & 0.88 & 0.10 & 0.10 & 0.01 & 1.57 & 0.37 & 0.023 \\
\hline
\end{tabular}

$\mathrm{Rh}=$ Rhizon sample. $-=$ no data are reported for samples with insufficient pore water volumes. 
Table T5. Total carbon (TC), total organic carbon (TOC), total inorganic carbon (TIC), and total sulfur (TS) in sediment, Site M0064.

\begin{tabular}{|c|c|c|c|c|c|}
\hline $\begin{array}{l}\text { Core, section, } \\
\text { interval }(\mathrm{cm})\end{array}$ & $\begin{array}{l}\text { Depth } \\
\text { (mbsf) }\end{array}$ & $\begin{array}{c}\mathrm{TC} \\
(\mathrm{wt} \%)\end{array}$ & $\begin{array}{l}\text { TOC } \\
\text { (wt\%) }\end{array}$ & $\begin{array}{c}\text { TIC } \\
(w t \%)\end{array}$ & $\begin{array}{c}\text { TS } \\
\text { (wt\%) }\end{array}$ \\
\hline \multicolumn{6}{|l|}{ 347-M0064A- } \\
\hline $1 \mathrm{H}-1,13-14$ & 0.13 & 2.66 & 2.29 & 0.36 & 0.81 \\
\hline $1 \mathrm{H}-1,51-52$ & 0.51 & 0.43 & 0.20 & 0.23 & 1.06 \\
\hline $1 \mathrm{H}-1,90-91$ & 0.90 & 0.72 & 0.29 & 0.43 & 0.13 \\
\hline $2 \mathrm{H}-1,110-111.5$ & 4.10 & 1.33 & 0.47 & 0.87 & 0.16 \\
\hline $3 \mathrm{H}-1,64-65$ & 6.94 & 1.31 & 0.54 & 0.77 & 0.20 \\
\hline $3 \mathrm{H}-1,83.5-84.5$ & 7.14 & 3.45 & 1.75 & 1.69 & 0.39 \\
\hline $3 \mathrm{H}-1,110-111$ & 7.40 & 1.75 & 0.46 & 1.29 & 0.20 \\
\hline $7 \mathrm{H}-1,32-33$ & 16.37 & 3.09 & 0.19 & 2.90 & 0.36 \\
\hline $10 \mathrm{H}-1,17-18$ & 18.67 & 1.93 & 0.28 & 1.65 & 0.40 \\
\hline $12 \mathrm{H}-1,4-5$ & 20.54 & 1.87 & 0.37 & 1.51 & 0.52 \\
\hline $15 \mathrm{H}-1,28-29$ & 23.78 & 2.01 & 0.34 & 1.67 & 0.43 \\
\hline $18 \mathrm{H}-1,62-63$ & 27.12 & 1.85 & 0.29 & 1.57 & 0.37 \\
\hline $20 \mathrm{H}-1,26-27.5$ & 28.76 & 1.61 & 0.28 & 1.33 & 0.44 \\
\hline $22 \mathrm{H}-1,68-69$ & 31.18 & 1.93 & 0.27 & 1.66 & 0.47 \\
\hline $24 \mathrm{H}-1,21-22$ & 33.71 & 2.16 & 0.31 & 1.85 & 0.41 \\
\hline $26 \mathrm{H}-1,70-71$ & 36.20 & 2.25 & 0.26 & 1.99 & 0.30 \\
\hline $28 \mathrm{H}-1,5-6$ & 37.55 & 2.16 & 0.28 & 1.88 & 0.31 \\
\hline \multicolumn{6}{|l|}{ 347-M0064B- } \\
\hline $1 \mathrm{H}-1,80-81$ & 0.80 & 1.52 & 0.61 & 0.91 & 0.14 \\
\hline $1 \mathrm{H}-3,30-31$ & 3.00 & 1.53 & 0.45 & 1.09 & 0.14 \\
\hline $2 \mathrm{H}-1,75-76$ & 4.05 & 3.19 & 0.32 & 2.86 & 0.38 \\
\hline $2 \mathrm{H}-2,81-82$ & 5.61 & 1.33 & 0.10 & 1.23 & 0.18 \\
\hline $3 \mathrm{H}-2,19-20$ & 7.11 & 1.85 & 0.09 & 1.76 & 0.21 \\
\hline \multicolumn{6}{|l|}{ 347-M0064C- } \\
\hline $1 \mathrm{H}-1,87-88$ & 0.87 & 1.92 & 0.47 & 1.44 & 0.17 \\
\hline $1 \mathrm{H}-3,26-27$ & 3.05 & 1.55 & 0.47 & 1.08 & 0.14 \\
\hline $2 \mathrm{H}-1,60-61$ & 3.90 & 1.76 & 0.55 & 1.21 & 0.16 \\
\hline $2 \mathrm{H}-3,4-5$ & 6.14 & 1.65 & 0.48 & 1.17 & 0.15 \\
\hline $3 \mathrm{H}-1,30-31$ & 6.90 & 1.74 & 0.45 & 1.29 & 0.16 \\
\hline $3 \mathrm{H}-1,80-81$ & 7.40 & 1.86 & 0.14 & 1.72 & 0.23 \\
\hline $3 \mathrm{H}-2,20-21$ & 8.30 & 3.44 & 0.26 & 3.18 & 0.37 \\
\hline $4 \mathrm{H}-1,37-38$ & 10.27 & 2.67 & 0.26 & 2.41 & 0.36 \\
\hline $5 \mathrm{H}-1,23-24$ & 12.93 & 3.19 & 0.25 & 2.94 & 0.33 \\
\hline $6 \mathrm{H}-1,56-57$ & 14.26 & 2.33 & 0.23 & 2.09 & 0.28 \\
\hline $13 \mathrm{H}-1,78-79$ & 22.48 & 3.06 & 0.24 & 2.81 & 0.35 \\
\hline $15 \mathrm{H}-1,85-86$ & 24.55 & 3.45 & 0.30 & 3.14 & 0.37 \\
\hline $16 \mathrm{H}-1,57-58$ & 25.27 & 2.06 & 0.27 & 1.78 & 0.45 \\
\hline $18 \mathrm{H}-1,72-74$ & 27.42 & 2.07 & 0.28 & 1.79 & 0.37 \\
\hline $20 \mathrm{H}-1,65-66$ & 29.35 & 1.98 & 0.29 & 1.68 & 0.47 \\
\hline $21 \mathrm{H}-1,37-39$ & 30.07 & 1.94 & 0.29 & 1.66 & 0.87 \\
\hline $22 \mathrm{H}-1,57-58$ & 31.27 & 1.90 & 0.26 & 1.64 & 0.40 \\
\hline $24 \mathrm{H}-1,100-101$ & 33.70 & 2.26 & 0.27 & 1.99 & 0.39 \\
\hline $26 \mathrm{H}-1,82-84$ & 35.52 & 1.93 & 0.26 & 1.67 & 0.30 \\
\hline $28 \mathrm{H}-1,71-73$ & 37.41 & 2.05 & 0.27 & 1.78 & 0.34 \\
\hline \multicolumn{6}{|l|}{ 347-M0064D- } \\
\hline $1 \mathrm{H}-1,65-66$ & 0.65 & 2.87 & 2.38 & 0.49 & 1.44 \\
\hline $1 \mathrm{H}-2,65-66$ & 2.15 & 0.30 & 0.23 & 0.06 & 0.11 \\
\hline $2 \mathrm{H}-1,90-91$ & 3.10 & 1.79 & 0.48 & 1.31 & 0.16 \\
\hline $3 \mathrm{H}-1,130-131$ & 6.80 & 1.36 & 0.47 & 0.89 & 0.24 \\
\hline $3 \mathrm{H}-2,100-101$ & 8.00 & 1.53 & 0.49 & 1.03 & - \\
\hline $4 \mathrm{H}-1,49-50$ & 9.29 & 2.37 & 0.38 & 1.99 & - \\
\hline $4 \mathrm{H}-2,84-85$ & 11.14 & 3.09 & 0.23 & 2.86 & 0.38 \\
\hline $5 \mathrm{H}-1,35-36$ & 12.45 & 3.09 & 0.26 & 2.83 & 0.40 \\
\hline $5 \mathrm{H}-2,49-50$ & 14.09 & 3.59 & 0.23 & 3.36 & 0.42 \\
\hline $7 \mathrm{H}-1,53-54$ & 16.93 & 2.73 & 0.23 & 2.50 & 0.24 \\
\hline $8 \mathrm{H}-1,66-67$ & 18.06 & 2.82 & 0.11 & 2.70 & 0.31 \\
\hline $8 \mathrm{H}-1,57-58$ & 17.97 & 1.87 & 0.24 & 1.63 & 0.22 \\
\hline $15 \mathrm{H}-1,40-41$ & 25.80 & 2.58 & 0.23 & 2.35 & 0.38 \\
\hline $16 \mathrm{H}-1,20-21$ & 26.60 & 1.89 & 0.27 & 1.62 & 0.42 \\
\hline $18 \mathrm{H}-1,70-71$ & 29.10 & 2.15 & 0.25 & 1.90 & 0.36 \\
\hline $19 \mathrm{H}-1,23-24$ & 29.63 & 1.85 & 0.25 & 1.60 & 0.38 \\
\hline $21 \mathrm{H}-1,37-38$ & 31.77 & 2.30 & 0.25 & 2.05 & 0.40 \\
\hline $22 \mathrm{H}-1,21-22$ & 32.61 & 1.61 & 0.26 & 1.34 & 0.34 \\
\hline $23 \mathrm{H}-1,7-8$ & 33.47 & 2.29 & 0.27 & 2.02 & 0.39 \\
\hline
\end{tabular}


Table T6. Composite depth scale, Site M0064.

\begin{tabular}{|c|c|c|c|}
\hline \multirow[b]{2}{*}{ Core } & \multirow{2}{*}{$\begin{array}{c}\text { Offset } \\
\text { (m) }\end{array}$} & \multicolumn{2}{|c|}{ Top depth } \\
\hline & & (mbsf) & (mcd) \\
\hline \multicolumn{4}{|c|}{ 347-M0064A- } \\
\hline $1 \mathrm{H}$ & 0.44 & 0.0 & 0.44 \\
\hline $2 \mathrm{H}$ & 0.14 & 3.0 & 3.14 \\
\hline $3 \mathrm{H}$ & 0.63 & 6.3 & 6.93 \\
\hline $4 \mathrm{H}$ & 0.63 & 9.6 & 10.23 \\
\hline $5 \mathrm{~N}$ & 0.63 & 12.9 & 13.53 \\
\hline $6 \mathrm{P}$ & 0.63 & 15.9 & 16.53 \\
\hline $7 N$ & 0.63 & 16.1 & 16.68 \\
\hline $8 \mathrm{~N}$ & 0.63 & 16.5 & 17.13 \\
\hline $9 N$ & 0.63 & 17.5 & 18.13 \\
\hline $10 N$ & 0.63 & 18.5 & 19.13 \\
\hline $11 \mathrm{~N}$ & 0.63 & 19.5 & 20.13 \\
\hline $12 \mathrm{~N}$ & 0.63 & 20.5 & 21.13 \\
\hline $13 N$ & 0.63 & 21.5 & 22.13 \\
\hline $14 \mathrm{~N}$ & 0.63 & 22.5 & 23.13 \\
\hline $15 N$ & 0.63 & 23.5 & 24.13 \\
\hline $16 \mathrm{~N}$ & 0.63 & 24.5 & 25.13 \\
\hline $17 N$ & 0.63 & 25.5 & 26.13 \\
\hline $18 \mathrm{~N}$ & 0.63 & 26.5 & 27.13 \\
\hline $19 N$ & 0.63 & 27.5 & 28.13 \\
\hline $20 N$ & 0.63 & 28.5 & 29.13 \\
\hline $21 N$ & 0.63 & 29.5 & 30.13 \\
\hline $22 \mathrm{~N}$ & 0.63 & 30.5 & 31.13 \\
\hline $23 N$ & 0.63 & 31.5 & 32.13 \\
\hline $24 N$ & 0.63 & 33.5 & 34.13 \\
\hline $25 \mathrm{P}$ & 0.63 & 34.5 & 35.13 \\
\hline $26 N$ & 0.63 & 35.5 & 36.13 \\
\hline $27 N$ & 0.63 & 36.5 & 37.13 \\
\hline $28 \mathrm{~N}$ & 0.63 & 37.5 & 38.13 \\
\hline $29 N$ & 0.63 & 38.5 & 39.13 \\
\hline $30 N$ & 0.63 & 39.5 & 40.13 \\
\hline $31 s$ & 0.63 & 40.5 & 41.13 \\
\hline $32 \mathrm{~N}$ & 0.63 & 40.5 & 41.13 \\
\hline \multicolumn{4}{|c|}{ 347-M0064B- } \\
\hline $1 \mathrm{H}$ & 4.91 & 0.0 & 4.91 \\
\hline $2 \mathrm{H}$ & 4.91 & 3.3 & 8.21 \\
\hline $3 \mathrm{H}$ & 4.91 & 6.6 & 11.51 \\
\hline \multicolumn{4}{|c|}{ 347-M0064C- } \\
\hline $1 \mathrm{H}$ & 1.73 & 0.0 & 1.73 \\
\hline $2 \mathrm{H}$ & 1.73 & 3.3 & 5.03 \\
\hline $3 \mathrm{H}$ & 1.73 & 6.6 & 8.33 \\
\hline
\end{tabular}

\begin{tabular}{|c|c|c|c|}
\hline \multirow[b]{2}{*}{ Core } & \multirow{2}{*}{$\begin{array}{l}\text { Offset } \\
\text { (m) }\end{array}$} & \multicolumn{2}{|c|}{ Top depth } \\
\hline & & (mbsf) & (mcd) \\
\hline $4 \mathrm{H}$ & 1.73 & 9.9 & 11.63 \\
\hline $5 \mathrm{~N}$ & 1.73 & 12.7 & 14.43 \\
\hline $6 \mathrm{~N}$ & 1.73 & 13.7 & 15.43 \\
\hline $7 \mathrm{~N}$ & 1.73 & 14.7 & 16.43 \\
\hline $11 \mathrm{~N}$ & 1.73 & 19.7 & 21.43 \\
\hline $12 \mathrm{~N}$ & 1.73 & 20.7 & 22.43 \\
\hline $13 N$ & 1.73 & 21.7 & 23.43 \\
\hline $14 \mathrm{~N}$ & 1.73 & 22.7 & 24.43 \\
\hline $15 \mathrm{~N}$ & 1.73 & 23.7 & 25.43 \\
\hline $16 \mathrm{~N}$ & 1.73 & 24.7 & 26.43 \\
\hline $17 N$ & 1.73 & 25.7 & 27.43 \\
\hline $18 \mathrm{~N}$ & 1.73 & 26.7 & 28.43 \\
\hline $19 \mathrm{~N}$ & 1.73 & 27.7 & 29.43 \\
\hline $20 N$ & 1.73 & 28.7 & 30.43 \\
\hline $21 N$ & 1.73 & 29.7 & 31.43 \\
\hline $22 \mathrm{~N}$ & 1.73 & 30.7 & 32.43 \\
\hline $23 N$ & 1.73 & 31.7 & 33.43 \\
\hline $24 N$ & 1.73 & 32.7 & 34.43 \\
\hline $25 N$ & 1.73 & 33.7 & 35.43 \\
\hline $26 N$ & 1.73 & 34.7 & 36.43 \\
\hline $27 N$ & 1.73 & 35.7 & 37.43 \\
\hline $28 \mathrm{~N}$ & 1.73 & 36.7 & 38.43 \\
\hline $29 N$ & 1.73 & 37.7 & 39.43 \\
\hline \multicolumn{4}{|c|}{ 347-M0064D- } \\
\hline $1 \mathrm{H}$ & -0.40 & 0.0 & -0.40 \\
\hline $2 \mathrm{H}$ & -0.31 & 2.2 & 1.89 \\
\hline $3 \mathrm{H}$ & -0.08 & 5.5 & 5.42 \\
\hline $4 \mathrm{H}$ & -0.08 & 8.6 & 8.52 \\
\hline $5 \mathrm{H}$ & -0.08 & 12.1 & 12.02 \\
\hline $7 N$ & -0.08 & 16.4 & 16.32 \\
\hline $8 \mathrm{~N}$ & -0.08 & 17.4 & 17.32 \\
\hline $11 \mathrm{~N}$ & -0.08 & 20.4 & 20.32 \\
\hline $12 \mathrm{~N}$ & -0.08 & 21.4 & 21.32 \\
\hline $15 \mathrm{~N}$ & -0.08 & 25.4 & 25.32 \\
\hline $16 \mathrm{~N}$ & -0.08 & 26.4 & 26.32 \\
\hline $18 \mathrm{~N}$ & -0.08 & 28.4 & 28.32 \\
\hline $19 \mathrm{~N}$ & -0.08 & 29.4 & 29.32 \\
\hline $21 \mathrm{~N}$ & -0.08 & 31.4 & 31.32 \\
\hline $22 \mathrm{~N}$ & -0.08 & 32.4 & 32.32 \\
\hline 230 & -0.08 & 33.4 & 33.32 \\
\hline
\end{tabular}

Table T7. Splice tie points, Site M0064.

\begin{tabular}{lcrll}
\hline $\begin{array}{c}\text { Hole, core, section, } \\
\text { interval }(\mathrm{cm})\end{array}$ & $\begin{array}{c}\text { Depth } \\
\text { (mbsf) }\end{array}$ & $\begin{array}{c}\text { Depth } \\
\text { (mcd) }\end{array}$ & & $\begin{array}{c}\text { Hole, core, section, } \\
\text { interval }(\mathrm{cm})\end{array}$ \\
\hline 347- & & & & $347-$ \\
M0064D-1H-2, 73 & 1.39 & 1.83 & Tie to & M0064A-1H-1, 139 \\
M0064A-1H-3, 19 & 3.65 & 3.34 & Tie to & M0064D-2H-1, 144 \\
M0064D-2H-2, 134 & 4.59 & 4.73 & Tie to & M0064A-2H-1, 159 \\
M0064A-2H-3, 49 & 4.60 & 6.33 & Tie to & M0064C-2H-1, 130 \\
M0064C-2H-3, 42 & 7.62 & 8.25 & Tie to & M0064A-3H-1, 131 \\
M0064A-3H-2, 91 & 7.62 & 9.35 & Tie to & M0064C-3H-1, 101 \\
M0064C-3H-3, 41 & 9.81 & 11.54 & Append & \\
\hline
\end{tabular}


Table T8. Sound velocities, Site M0064.

\begin{tabular}{lcccrr}
\hline Unit & $\begin{array}{c}\text { TWT } \\
(\mathrm{ms})\end{array}$ & $\begin{array}{c}\text { Thickness } \\
\text { of unit } \\
(\mathrm{m})\end{array}$ & $\begin{array}{c}\text { Sound } \\
\text { velocity } \\
(\mathrm{m} / \mathrm{s})^{*}\end{array}$ & $\begin{array}{c}\text { Depth } \\
(\mathrm{m})\end{array}$ & $\begin{array}{r}\text { Depth } \\
(\mathrm{mbsf})\end{array}$ \\
\hline Seafloor & 0.0811 & 59.8 & 1475 & 59.80 & 0.00 \\
I & 0.0829 & 1.34 & 1450 & 61.14 & 1.34 \\
II & 0.0835 & 0.41 & 1500 & 61.55 & 1.75 \\
III & 0.0919 & 6.12 & 1449 & 67.67 & 7.87 \\
IIIb & 0.0938 & 1.43 & 1530 & 69.10 & 9.30 \\
IVa & 0.1116 & 16.1 & 1807 & 85.20 & 25.40 \\
IVb & 0.1241 & 11.3 & 1804 & 96.50 & 36.70 \\
IVc & 0.1332 & 8.3 & 1825 & 104.80 & 45.00 \\
\hline
\end{tabular}

* = sound velocities are based on values measured during the OSP. 